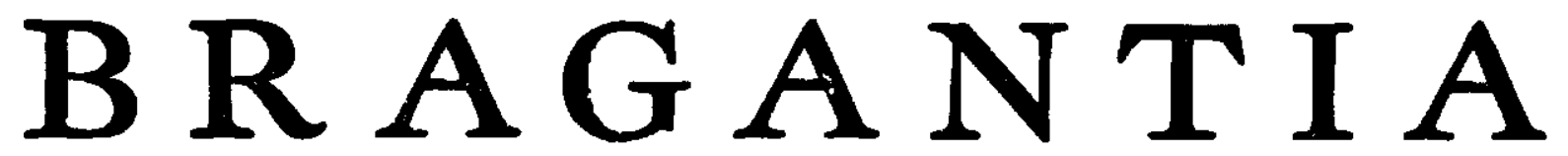

Boletim Técnico da Divisão de Experimentação e Pesquisas IN S TITUTO AGRONÔMICO

Fol. 5

Campinas, Novembro de $\mathbf{1 9 4 5}$

No. 11

\title{
ESTUDOS SÔBRE A INFLORESCÊNCIA DE MILHO COM REFERÊNCIA ESPECIAL AOS PROBLEMAS FILOGENÉTICOS
}

F. G. Brieger (*)

\section{INTRODUÇÃO}

\section{O problema}

O objetivo inicial dos nossos estudos sôbre as inflorescêneias nas Maydeae americanae era bem limitado. Fazendo um detalhado estudo botânico e genético, esperávamos compreender perfeitamente a estrutura, para depois tirar conclusões sôbre a natureza mais provável das inflorescências do milho selvagem e sôbre sua evolução para aquelas do milho cultivado. Mas, durante o trabalho, se tornou claro que as conclusões tinham um alcance bem maior, permitindo generalizações sôbre 0 processso de evolução.

Estudos sôbre o mecanismo da evolução em geral e sôbre a filogenia cle determinados gêneros ou espécies, são realmente aspectos de um mesmo fenômeno sendo, porém, bastante diferentes os métodos científicos, necessários para a soluȩão dêsses problemas.

No primeiro caso temos que enfrentar um problema bem geral, e podemos juntar resultados obtidos em experimentos diferentes, com material bastante diverso, como demonstramos, por exemplo, numa publicação anterior Brieger (5). Experimentos de genética fundamental e estudos genético-estatísticos sôbre populações, muito contribuiram, recentemente. para tornar mais concisas as nossas idéias gerais sôbre os mecanismos da evolução.

${ }^{*}$ Catedrátito da Cadeira de Cito-Genética da Escola Superior de Agricultura "I.uiz de Queiroz". 
Por outro lado, quando queremos estudar um problema limitado a origem de $\mathrm{nm}$ determinado gênero on de uma espécie - temos, en? grande parte, que aplicar os métodos científicos antigos, descritivos e comparativos, porém em combinação com os métodos modernos da genitica experimental, como ficou demonstrado no caso do milho pelos tribalhos de Mangelsdorf e Reeves (15) e Brieger (4, 5, 6).

A situação torna-se ainda mais complicala quando tentamos analis: $\mathrm{l}^{\circ}$ e compreender a evolução filogenética de um grande conjunto de gêneror. nma família ou uma ordem sistemática. Ayui se aplicam quase sempri. apenas os métodos antigos, descrevendo todos os gêeneros e comparando-ns com o fim de arranjá-los em séries filogenéticas. Esta é, em parte. rinna dis. finalidades do livro de Agnes Arber (1) sôbre as Gramineap que citamus como exemplo. As séries filogenéticas assim organizadas são, porém. umi: abstração que serve apenas para ilustrar "omo a filogenia polia ter-s.; lado, sem ter real valor, pois os gêneros e as espécies, hoje existent is. não são meros descendentes um dos outros, mas, ao contrário, são descenlentes que se desenvolvaram filchenèticamente de ancestrais que náo mair existem. Esta situação se torua muito clara quando tentamos uma seriațào das mesmas espécies ou gêneros com referência a diferentes caraterísticos. observando-se, então, que a sequência não é a mesma em tôda as séries. Concluimos que existem certas tendèncias filogenéticas, as quais determinam a rariação da evolução e as divergências dos gêneros e espéciex lo mesmo grupo sistemático.

No presente trabalho aplicaremos $17 m$ outro processo para chegar a uma compreensão da filogenia da inflorescência clas Maydeae, analisantu. do ponto de vista botânico, $\mathrm{mm}$ número de formas que apareerem nos últimos nove anos, em nossos estudos genéticos com milho. Teutaremos. assim, chegar a compreender as possibilidades filogenéticas ainda inerentes a esta espécie.

IIm estudo detalhado (la filogenia das Gramineae, pelo método clássico, mostra que dois fenômenos acompanharam a sua evolução: uma redução muito pronunciada dos órgãos ftlorais e um paralelismo da evoluçãu em diferentes grupos sistemáticos. Mostraremos que a variação em milhu oferece material que ajuda esclarecer ambos êstes problemas. O milho ronstitui um material especialmente favorável em vista da sua grande variabilidade, a qual, no início, nos parecia desordenada. Um estudo mais detalhado provou que certas formas continuamente aparecem de modo que não poderiam ser consideradas como raras e isoladas exceções, mas comu ıma documentação das tenclênuias filogenéticas inerentes.

Além destas conclusões mais gerais, aproveitaremos o material. apresentado para aprofundar os nossos conhecimentos sôbre a filogenia do próprio milho.

\section{Material}

Inicianos os estudos com o milho tunicata paulista. O efeito múltiplo to gen Tu sôbre o fenótipo de rários órgãos foi descrito em detalhe pôl 
Brieger $(4,5,6)$. Obtivemos. por selegăo, linhage ws nas quais a tramsformação da flecha. isto 'a, da inflorescência terminal masculina, num órgão intermediário entre a flecha e a espiga chegou a um extremo que, provàvelmente, constitui o máximo que se pode obter. $O$ eixo central então se transformou em uma espigara com muitas fileiras e com ráquis flexivel, sendo as flores ou femininas on herniafroditas. As ramifieacooses continuam a ter quatro fileiras de espignetas com flores masenlinas, femininas ou hermafroditas. Um estudo mais detalhado dessas flechas, apresentado nesta publicação, revelnu alterações na estrutura dos pares de espiguetas, as quais se transformaram em inflorescências complexas, mas perfeitamente normais.

Outra alteração observada refere-se à estrutura das próprias expiwuetas. Normalmente, encontramos nas espiguetas masculinas chus thores férteis e nas femininas uma flor feminina e outra abortiva. Nas flechas transformadas aparecem flores hermafroditas, cujo número por espigueta pode ser grandemente aumentado.

Estas observações feitas em milho tunicata paulista nos levaram a fazer um estudo mais geral sôbre a estrutura das inflorescências e das flores em milho. Usamos especialmente material sul-americano, que ati hoje foi pouco aproveitado. As observações mostram que as particularilades observalas no milho tunicata se encluad am num esquema beni geral.

Finalmente, usamos também os descendentes de híbridos entre varjedades de $Z$ ea mays e Euchlaena mexicana. O aproveitamento dêste matel'ial, em estudos sôbre filogenia das Maydeue é perfeitamente justificado. uma vez que ambas as espécies pertencem a êste grupo. $O$ valor dêstes híbridos. para os estudos sôbre a origem do milho, reside no seg̣ninte: Torna-se indispensável substituir os muitos gens acumulados em milho durante a domesticação, por outros de nma espécie selvagem, e o rinion caminho, no momento, í a sua substituição por gens de teosinto, como já explicamos em detalhe em ontro lugar, Brieger (4 e 6).

\section{A estrutura da flor e das espiguetas em milho}

A estrutura, cue muitas vêzes is chamada "flor" de uma gramínea, $\dot{E}$, de fato, uma pequena inflorescência, protegida por um certo número de brácteas. Êste conjunto chamamos de espigueta e a sua estrutura está esquemàticamente representada na fig. 1, d. Do eixo principal E sai uma ramificação lateral, que clevia estar na axila de uma fôlha, a qual. às vêzes, ainda é representada por unı pequena eleração na base dessa ramificação. A ramificação tem, em primeiro Jugar. duas ou mais brácteas, chamadas glumas estéreis, e que são, em geral, os principais órgãos protetores (Ge e Gi nas figuras). Depois segne um uńmero, variável nas diferentes sub- famílias das Grominue. lle bráteas férteis chamadas glumas floríferas on Lema $(\mathbf{L})$. também ilesignalas como "pálea inferior", estando as flores nas suas axilas. Representamos, na fig. 1,d, apenas duas lemas rom as duas flores nas suas axilas. Assim, as glumas estéreis pro- 
tegem tôda a espigueta, sendo as lemas os úrgãos especiais para cada flor. Além disso, cada flor tem mais um órgão protetor, a púlea superior on simplesmente pálea (P), e que já faz parte da própria flor. Em alguns gêneros, o eixo da espigueta ou ráquila (Et) produz, finalmente, mais algumas brácteas sem flores, en cima da zona florífera.

A estrutura de uma espigueta com uma só flor á também ilustrada jelo diagrama na fig. 1,b e 1,c, onde toram usadas as mesmas letras parit o eixo principal (E), o eixo da espigueta (Et), as glumas estéreis (Ge e Gi), a lema (L) e pálea (P).

A flor das gramíneas (fig. 1,b e 1,c) pode ser melhor compreendida qliando a comparamos com uma flor completa de uma Liliacea (Fig. 1,a). - Para tornar os diagramas comparáveis representamos uma flor que estí 11 um ramo lateral (Et) protegido por três brácteas (B1, B2, B3), colocalla ua axila da última bráctea. Na flor das Liliaceas temos dois círculos: de 3 pétalas cada um, dois círculos de três estames cada um e um círculo de três carpelos reunidos num ovário, sendo a posição nos círculos adjacentes sempre alternada. Nas Gramineae (Fig. 1,b), o primeiro círeulo contém desenvolvidas apenas duas das três pétalas, unidas na formaçãı da pálea (P), sendo a terceira pétala completamente ausente. Do círculo interno de fôlhas sobram dois pequenos órgãos bractóides, as lodículas (1), que, pela variação do seu volume, forȩam durante a antesis a abertura dos órgãos protetores, permitindo a saída das anteras e estigmas. Apenas o círculo externo de anteras é geralmente desenvolvido. Do círculo dos earpelos, aparecem, em geral, apenas dois carpelos bem desenvolvidos. terminando num estigma dividido mais on menos profundamente em cluas pontas. $O$ ovário contém uma cavidade única com $\mathrm{um}$ só óvulo. É interessante notar que, no grupo das Bambusaceae (Fig. 1,c), eneontramos $\mathrm{mm}$ tipu um pouco mais simples, sendo desenvolvidos todos os três membros (lo éreulo interno de pétalas e dois círculos completos de estames. En arriz. encontramos também dois círeulos de estames.

A. redução dos órgãos florais de cada flor na Gramineae é contrabalançada pela reunião de mais de uma flor dentro de cada espigueta, senrlo assim esta última a unidade básica das inflorescências.

As reduções especiais encontradas nas Maydeae são as seguintes: tồlas as espiguetas contêm apenas duas flores, em vez de muitas, e ainda há uma separação dos sexos. Nas espiguetas femininas sòmente a flor superior é desenvolvida, sendo suprimidos todos os órgãos da flor inferior: exceto a pálea e a lema (fig. 2,a c fig. 3,a), estando, porém, no diagrama (fig. 2.a) ainda representadas as anteras na flor superior. Nas espiguetas masculinas temos duas flores férteis. cada uma com três estames, (fig. 2.b e fig. 3,b). estando no diagrama (fig. 2.b) ainda representados os ovários.

Esta redução, nas espiguetas, a uma flor feminina ou a duas masen. linas é compensada em parte pela formação de duas espiguetas conjugadas em cada nó do eixo. incluídas numa pequena cavidade chamada alreolo (fig. 3,e), limitada. em milho, na base e nos lados por uma pequena 
elevacão bractóde. A mesma estrntura bractride forma, em Tripsacum e Euchlaena, as "tapas" ou órgãos protetores externos. É interessante notar que as Maydrue contêm. nos alróolos da parte masculina das inflorescências, duas espignetas, sendo frequientemente uma espigueta séssil e outra peduneulada. Na parte feminima, porém, existe uma diferença entre os gêneros americanos. Em Zea temos também na espiga duas espiruetas e, consequientemente. dois grãos por alvéolo, o que é a causa do aparecimento de fileiras conjugadas. Em Euchlaena e Tripsacum uma das espiwnetas é suplimida: encontramos em $T$. anstrule apenas, como rara antrmalia, o desenvolvimento de duas espignetas na base da inflorescência, podendo ser ambas fêmeas on também de sexo diferente.

$O$ aparecimento de duas espiguetas por alvéolo em milho den origem a muitas discussones, apesar de que em outras Gramineae situacoon análogas não são raras. Assim. temos, em cevada (ITordeum), como nuidade La espiga, grupos de três espiguetas eonjugadas. e Arber (1) explica. $\mathrm{cm}$ letalhe, tipos ainda mais complicados. como o gênero sul-americano Pariana (1 po. 170). Podemos citar também as "contas" de Coix, nas utais estão reuniclas duas espiguetas estereis e uma terceina fértil e feminina.

Para explixal o aparecimento das duas expiguetas ronjugalas em milho, Collins (9) formulon a lipótese de que se trata dos restos de rim ramo lateral reduzido apenas a duas espiquetas. Esta bipótese foi depis.s aceita por Weatherwax (20, 21) e Mangessdorf and Reeves (15), (pg. 59). Adotamos também esta hipótese, e, para ilustrá-la, referimo-nos ao desenho na fig. 3,f, na qual é representado, no alvéolo, um rano rom três espignetas.

Assim, constatamos nas Maydeac americanac, além da redusão dos ireãos florais típica para as Grominete om geral. mais duas peenliarilades, adquilidas durante a evolucão filogenética regressiva: a) redura das flores por espigueta a duas, das quais apenas a superior fértil nat parto feminina das infloreseências, e b) a relução de ranos secundírios. a cluas espiguetas, tanto na espiga do milho como nas partes mascmlinas

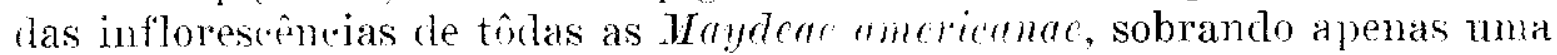
las espiguetas nas partes femininas das inflorescências de Triprocmm e Euchlaena.

Além da diferenca no desenvolvimento das tapas protetoms an fileiras duplas nos três gêneros mencicnarlos, temos outra difereng "ntre hes no desenvolvimento da ráquis. Na parte feminina da infloresurnina le Tripsaum a ráquis é quase reta com concavidades alternadas nos duir lados, correspondendo às espiguetas. Em Euchlaena temos na espiga uma Jáquis que forma um zigue-zag'ue, sendo as espiguetas colocarlas nos espaej.triangulares formados pejo eixo. No milho eultivado, finalmente. a ritulus ¿ reta, sem conravidarde e as espiguctas são colocadas na sua supertíle. formando um âneulo quase reto com a ráquis. Is vêzes, nas flechas transformadas do milho tunioata, encontramos nos ramos laterais nm eixo an zignezagne. como também has pontas is rêzes muito fiuas das espigas 


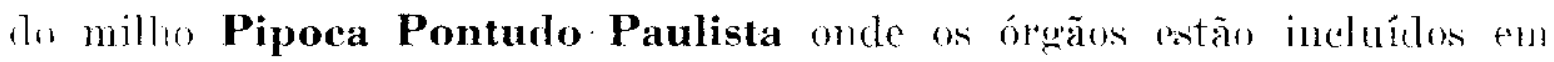
(oncavidarles da ráquis.

Devemos ainda mencionar uma peculiaridade em milho que é, provìvelmente, um resultado da domesticação: a multipljcação das fileiras. Nas inflorescêneias de Euchlac no Tripsacum a nos ramos das flechas do milho cheontramos os alvéolos numa filotaxia em espiral $1 \frac{2}{2}$. quando no pixo central da flecha e na espiga do milho temos um número variável de fileiras longitudinais de alvéolos. Esta substituição da filotaxia em espiral pela organização de fileiras longitudinais será assunto para um estudo detalhado, mas se trata realmente de um fenômeno bastante comum. Basta lembrar que um fenomeno idêntico é encontrado em muitas outras plantas, por exemplo, nas Cactaceae, em que a espiral de fôlhas é suplantada por uma organização longitudinal eom 2, 3, 4 fileiras, conforme o :pênero ou a espécie Brieger (6).

Em resumo, aceitando as rárias sugestões contidas na literatura (reja-se "ótimo rt sumo em Mangelsdort' and Reeves (15) e anpliando us numerosos pont s, podemos caraterizar a filogenia da inflorescencia das Maydeae americanae da forma seguinte:

a) Redução dos órgãos florais, comum para a maioria das Gramineae, de uma tlor simétrica com 5 círeulos completos para 4 círeulos incompletos.

b) Redução das espiguetas a duas flores, sendo apenas uma fértil quando feminina, ou as duas, quando masenlinas.

c) Redução de um ramo lateral no máximo a duas espigutetas, ambas sésseis ou uma séssil e ontra pedunculada.

d) Substituição, em milho apenas, na espiga e no eixo central da lecha de uma filotaxia dos alvéolos en espiral de $1 / 2$. por uma simetria longitudinal com um número variável de fileiras.

Nos rapítulos seguintes relataremos un certo número de casos em que estas reduções filogenéticas foram anuladas em milho.

\section{A VARIABILIDADE NAS INFLORESCENCLAS}

\section{Flores hermatroditas}

Flores hermafroditas são tão commus em milho, que uma descricão detalhada nos parece supérfllna. Filas são encontradas nas flechas de indiríduos tunicata ou das várias formas denominadas "tassel seed" e também nas espigas de vários tipos anōes, hereditários. Uma vez que nas tlores masculinas existem quase sempre rudimentos do ovário e nas flores femininas rudimentos dos estaues, as flores hermafroditas não mostram fualquer alteração profunda da estrutura floral. São freqüentementi. "neontratas transicoes de flores monossexuais para flores hermafroditas. Ansini. encontramos em flores ainda masculinas, no lugar do ovário muito rudimentar, um filamento grosso de alguns milímetros de comprimenti. Fim flores ainda femininas encontramos filamentos ou mesmo estames

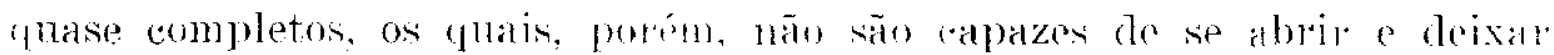
sair o pólen. 
Nos diagramas fllorais, que constam déste trabalho, está representada. para simplificação, a estrutura de flores hermafroditas. Os esquemas de flores unissexuais podem, fàcilmente, ser derivados pela omissão dos símbolos representando os estames ou os ovários.

\section{A estrutura das espiguetas}

\section{a) Espiguetas biflorais}

Como já ficou acima explicado, consideramos a espigueta como um ramo reduzido a apenas duas flores. Como estão localizadas nas faces :postas do eixo da espigueta (fig. 2,a e 2,b), a estrutura das flores a inversamente simétrica. As páleas das duas flores estão encostadas uma a outra, e as lemas exteriormente estão opostas, formando um envólucro dentro das duas glumas. $O$ embrião, também indicado nos esquemas por unn espaço em branco, está ao lado do ovário, oposto à pálea e por isso virado para fora em relação ao eixo (Et) da espigueta.

Nas espiguetas normais femininas de Maydeae, encontramos desenvolvida apenas a flor superior, isto é, a segunda flor da espigueta. Uma rez que em milho a espigueta forma um ângulo quase reto com a ráquis o embrião acha-se virado para a ponta da espiga. Em Tripsacum e em Euchlacna, nas quais as espiguetas são encostadas ou embutidas dentro do eixo cla espiga, o embrião encontra-se encostado a êste, no lado interno da espigueta, e assim muito melhor protegido do que em milho.

$\mathrm{O}$ desenrolvimento de ambas as flores femininas ocorre em algumas variedades de milho, como no milho doce "(ountry Gentleman", e Cutler (10) clescreven reentemente tais formas sul-ameriranas, fazendo também um resumo de literatura. Nestes casos, temos então pares de grãos, um dêles eom o embrião virado para a ponta e outro para a base da espiga. O mesmo autor observou, em milho Boliviano denominado "euti sara". um caso interessante: o desenvolvimento seja da segunda flor on seja da primeira flor na espigueta. Dêste modo, o grão tem o embrião virado para a ponta da espiga, quando originado da flor superior, on virado para it base da espiga, quando formado pela flor inferior, que a a primeira flur da espigueta.

Encontram-se comumente nas flechas normais masculinas, espiguetas hiflorais (fig. 3,b), mas quando há transformação em flores femininas. como em algumas plantas Tunicata ou "Tassel seed", a primeira flor em geral aborta e somente a segunda se torna feminina (fig. 3,a). Não obserramos ainda exceçóes a esta regra nos tipos de "Tassel seed", porém em algumas plantas de Tunicata, que pertenciam a linhagens selecionadas para um maior número de grãos maduros na espiga, encontramos, com bastante trequência, espiguetas biflorais férteis, sendo ambas as flores femininas ou hermafroditas (fig. 3,c. fig. 4,d, fig. 5,c, 5,g, fig. 6,d). 


\section{b) Espiguetas triflorais}

Observamos nas flechas de várias plantas Tunicata, espignetas triflorais, e pode-se entender fàcilmente a sua morfologia pelos diagramas nas fig. 2,c e fig. 3,d. A terceira flor da espigueta deve estar sempre no lado externo do eixo e, por isso, em cima da primeira flor, mostrando a mesma posição e simetria desta. Assim, quando tôdas as três sementes forem bem desenvolvidas, devenos esperar que dois embriões estejam rirados para a base da espiga, e apenas o embrião da segunda flor: a desenvolvimento é normal, esteja virado para a ponta da espiga.

Reproduzimos nas fig. 5 , i, j, l alguns dos casos observados, nos quair podemos verificar o número de sementes duma espigueta, incluídas entre o par das glumas e separadas entre si pelas lemas e páleas. 1 posiçãu dos embriōes não é bem visível nas reproduções fotográficas.

Inspecionando grande número das flores destas flechas encontramos. freqüentemente, espiguetas com apenas duas sementes, nas quais, porim, a posição dos embriões parecia anormal. Estes casos se explicam comn $n$ das espiguetas triflorais, sendo, porém, uma das flores abortiva. Quanibo a primeira flor é abortiva, os embriões da segunda e terceira fíor s' encontram em posições opostas, um virado para cima e outro virado para baixo (fig 2,d). Quando, ao contrário, a segunda flor se torna estéril. ambos os embriões das flores restantes são virados para a base da espiṇa (fig. 2,e). Em ambos os casos eneontramos, entre uma das sementes e as glumas, um número excessivo de brácteas, - a lema e, às vêzes, a pálea da flor estéril - além dos órgãos das flores férteis.

\section{c) Espiguetas multiflorais}

Apesar de, na maioria clos casos, ser três o máximo de flores femininas on hermafroditas férteis que temos observado até agora, o númeri total pode ser ainda maior, pois já tivemos oportunidade de encontrar cinco flores. Não são raros os casos em que se fundem órgãos vizinhrs destas flores, sendo, alóm disso, a quarta e a quinta flor sempre incomple. tas. Considerando que as espiguetas triflorais aparecem apenas depois $d e$ cinco anos de seleção, será talvez possível obter, no futuro, espiguetas de um número ainda maior de flores férteis.

Os óvulos de ovários fundidos podiam dar sementes dentro do mesmo pericárpio, nascendo assim grãos "conatos". Tais grãos "conatos" foram (lescritos por Kempton (13) em milho indígena norte-americano ("Hopi" ? e num líbrido entre milho "chinês" e central americano. Êles tambinin foram observados por Blaringhem (3) e Stratton (18) na rariedade "polyssperma" (citações segundo Randolph, (17),

\section{d) Protoginia}

Na descriçâo anterior não levamos em consideração una das liferenças entre flores femininas e masculinas. Nas flopes da flecha. com ovárion bem desenrolvidos, encontramos, de fato, uma variação muito grande. 
tanto de número de estames formados, que varia de zero até três, como do grau de desenvolvimento dos mesmos, desde filamentos estaminóides com anteras incapazes de se abrirem até estames completamente normais.

As nossas observações foram bastante dificultadas pela acentuada protoginia das flores. As anteras saem das glumas e deixam escapar 0 pólen no mínimo 8 até 10 dias depois da saída das barbas nas mesmas inflorescências, isto é, quando as barbas em parte já começam a secar. A mesma protoginia também pode ser observada na forma "tassel seed". Assim, as flechas dêstes tipos de milho, com as flores masculinas e femininas respectivamente hermafroditas, na mesma inflorescência, roltam ao estado encontrado em Tripsacum, em que em cada inflorescência, também mista, a protoginia í igualmente muito acentuada. Devemos assinalar que esta protoginia extrema é encontrada apenas com referência a flores dentro da mesma inflorescência ou a órgãos florais da mesma flor. As referências na literatura à protandria em milho dizem respeito às flores: em inflorescências separadas : as flores masculinas na flecha e as flores femininas da espiga lateral. Parece que esta diferença botânica, muito importante, entre a protoginia das flores femininas e basais da inflorescência de Tripsacum de um lado, e a protandria do outro, das flores na flecha terminal sôbre aquelas das espigas laterais em $Z$ ea e Euchlaena, não foi notada pelos autores que compararam êstes três gêneros (Mangelsclorf and Reeves (15), pg. 205).

\section{e) Conclusão}

Para finalizar, encontramos nas espiguetas mistas das flechas do milho tunicata paulista, selecionado para obtenção de um extremo grau de diferenciação em relação à flecha comum do milho, uma reversão filogenética regressiva em dois sentidos:

a) As flores voltam em grande parte à fase hermafrodita e os promórdios de todos os órgãos masculinos (estames) e femininos (ovários uni-ovulares) se desenvolvem ambos normalmente, observando-se ainda uma protoginia muito pronunciada.

b) Apesar de as espiguetas femininas em milho serem em geral providas de uma flor fértil e outra estéril, encontramos espiguetas com um máximo de três grãos perfeitos, quando maduros. Foram observadas até agora espiguetas com quatro ou cinco flores, ficando, porém, algumas das flores rudimentares e imperfeitamente desenvolvidas.

\section{Substituição de pares de espiguetas por racemos}

\section{a) Reversão das flechas em milho tunicata}

Mencionamos acima a hipótese de Collins (8), a qual é aceita posteriormente por outros autores, de que cada par de espiguetas nas Mydcre americanae corresponde a uma ramo reduzido que antigamente tinla numerosas espiguetas, arranjadas num racemo com a filotaxia de $1 / 2$. Foram encontrados vários casos de uma reversão a esta fase filogenètic mente primitiva, nas flechas transformadas do milho tunicata paulista: e estão reproduzidos algums casos nas fig. 4 e 6 . 
Antes de entrar em detalhes, explicaremos a situação esquemàticamente $\mathrm{com}$ a ajuda das fig. 3,e e 3,f. Na fig. 3 ,f temos un pequeno ramo com thès espiquetas : a primeira normal feminina com uma flor estéril; a segunda com duas flores hermafroditas e a tereeira, com duas flores masculinas. $\mathrm{Na}$ base de cada espigueta encontramos uma pequena articulação yue corresponde ao lugar onde havia antigamente uma bráctea. Dêste tipo podemos fàcilmente derivar, tanto a forma normal, como as auormaliclades encontradas em tunicata. Por exemplo, se supusermos que o ramo tenha apenas duas espignetas e que o primeiro internódio ficou tão reduzido em tamanho de modo que a segunda espigueta se tornou pràticamente séssil. chegaremos à sitnação do alvéolo normal, representado pela fig. 3 ,e.

A variação das estruturas observadas en flechas de plantas tunicata (lepencle de três fatôres : a) do comprimento dos internódios; b) do comprimento dos pedúnculos de cada espigueta, e, finalmente, e) do número de espiguetas por ramo.

Na forma mais aproximada ao normal, temos duas espiguetas por alvéolo, sendo ambas sésseis ou uma séssil e outra pedunculada. Encontramos esta situação nas fig. 4, e, l e fig. 5, a, b. e, g, h, k, l. Nas duas finuras .j.i e j encontramos duas espiguetas séssejs por alvéolo, uma com très e ontra com duas flores férteis, contendo grãos maduros. As últimas figuras, $\mathbf{k}$ e $\mathbf{l}$, mostram dois alvéolos carla $\mathrm{um}$ em espiguetas sésseis 011 pedunculadas, biflorais ou triflorais.

0 extremo oposto, o maior desvio do normal, encontramos nas fig. t, d e f. A figura 4, f, da planta 2-706-43, corresponde quase perfeitamente ao nosso esquema da fjg. 3,f, exceto que o racemo contém quatro espiguetas. A fig. 4, a até c, da planta 121-595-44. contém três espiguetas. tôdas com internódios curtos e os pedúnculos desenvolvidos. Muito intelessantes são ainda as três espiguetas da planta 54-14-42, ilustradas na fig. t.g.h,i. . . fi fig. 4,g temos uma espigueta grande séssil, seguida de dois internódios. o primeiro muito longo e o segundo curto, ambos terminados lor espiguetas pequenas. Na fig. 4, i também notamos três espiguetas, lias quais a maior é séssil; as outras têm pedúneulos longos, sendo, por outro laclo. os internódios reduzidíssimos. A fig. 4, h, finalmente, tem IIm aspecto normal com duas espiguetas, uma séssil e outra pedunculada.

Não temos dúvida de que as interpretações dadas são corretas e que t'mos vários estágios da formação, mais ou menos completa, de um racemo lateral. F interessante notar que nestes exemplos escolhidos não apareç qualquer coonstância referente à distribuição das espiguetas femininas ou masculinas, que tanto podem ser colocadas na base, como nos internódios superiores do racemo. Daí resulta o aspecto bastante irregular que as Jamifinacoies da flecha apresentam (fig. 6). Os alvéolos isolados nas fig. \pm e $\overline{5}$ correspondem sempre a rma das duas fileiras formadas normalmente en lados opostos das ramificacooes da flecha. Apenas a fig. 5, k e 1 . reprodn\% dois alvéolos opostos. 


\section{b) Aumento do número de espiguetas por alvéolo nas espigas}

Depois de verificado que o número de espiguetas por alvéolo nas flechas pode ser maior do que 2, resolvemos procurar inclicios de $10 m$ tal aumento também nas espigas.

$O$ s descendentes do cruzamento milho $\mathbf{x}$ teosinto oferecem, par: isso, material excelente. Não são raros os casos em que o número de fileiras de alvéolos é reduzido a apenas dois, o que facilita muito a análise. Além disso, encontramos, no desenvolvimento das tapas, uma outra ajuda para identificação dos alvéolos.

Reproduzimos na fig. 7 vários aspectos da mesma espiga de uma planta (7-486-44). As duas apresentações dorsal e ventral, na fig. 7, d e 7; e, mostram que temos duas fileiras de alvéolos, nos lados da ráquis. A estrutura talvez não seja muito fácil de se compreender nas fotografias, mas a fig. 7 ,a mostra um grão em detalhe aumentado. Notamos sempre muito bem a "tapa", o órgão protetor formado pela ráquis, que é acentuadamente desenvolvido em consequência da ação de gens do teosinto. Na tig. 7. a, $\mathrm{d}$, e e, as tapas são bem distintas pelas suas manchas pretas. Parcialmente cobertas pelas tapas, temos as glumas, especialmente a gluma externa, que é também muito dura e que forma um funil assimétrico (fig. ia e c). Finalmente, os grãos grandes são deformados, pois a sua base tem que se adaptar à forma das glumas córneas (fig. 7, b).

Estão reproduzidas na fig. 7, $f \mathrm{e} g$ os dois aspectos laterais da mesma espiga. O normal, nestes descendentes do cruzamento milho $\mathrm{x}$ teosinto, $C$ a presença de duas fileiras de grãos por alvéolo (tipo milho) ou de apenas uma fileira de grãos (tipo teosinto). As fotografias, porém. mostram claramente que a planta 7-486-44 tinha três fileiras de grãos por fileira de alvéolo. $\Lambda$ espiga tinha, assim, um total de $2 \times 3=6$ fileiras :

$T \mathrm{~m}$ (:aso semelhante reproduzimos no fig. 8, c e d, da planta 10-488-44. - Tqui também é claro que a espiga tinha apenas duas fileiras de alvéolos. nos Jados opostos da ráquis, posta em destaque pelas tapas, em preto ifig. 8 ( ). A vista lateral prova que muitos dos alvéolos contêm três expiguetas (fig. 8,d).

Para explicar êste fenômeno se oferecem duas possibilidacles : pode-se tratar ou de três ou de duas espiguetas, tendo uma delas mais de um grano desenvolvido. A segunda hipótese pode, porém, ser excluída imediatamente pela presença de glumas individuais para cada grão e pela orientação dos embriōes que são sempre virados para a ponta da espiga. Assin. resta apenas a outra alternativa : a formação de três espiguetas por alvéolo.

Estas observações sôbre a possibilidade do aumento do número de "spigutetas, por alvéolo, oferecem uma explicação para um fenômeno não raro em milho. É muito comum encontrar-se espigas que têm os grãos irranjarlos em fileiras bem regulares. exceto na base. Nesta zona podemos 'rimstatar uma ausência da regularidade das fileiras e, ao mesmo tempo, um aumento do número de grãos colocados à mesma altura na espiga. Is espigas do milho pipoca pontudo paulista nos deram ótimo material 
para o estudo dêste fenômeno, pela seguinte razão: nos dois on trés quartos superiores da espiga temos. em geral, fileiras que além de serem muito regulares são bastante salientes, ficando assim fácil idlentificn os pares de fileiras de espiguetas correspondendo a uma fileira de alreolos. Além disso, é fácil identificar as espiguetas individualmente. pois as glumas são bem desenvolvidas, mesmo em grãos maduros. Por outr: lado, ao contrário dos descendentes do cruzamento milho $\mathrm{x}$ teosinto, as tapas são pequenas, como é a legra no milho brasileiro. Na base da espig̣a não há regularidade das fileiras.

As fotografias (fig. 9, a e 9.b) ta planta 8-571-42, tomadas de ânğulus diferentes, demonstram a protunda separação das fileiras de alvéolos. Na fig. 9, a destaca-se, no eentro da espiga, uma linha preta rue colresponde à profunda separą̧ão de duas fileiras de alvéolos, à direita e à esquerda. Esta linha divisória pode ser vista desde a ponta até it base da espiga. Na fig. 9,b arentuanos estas linhas de separaçào wh alvéolos, pela inserção de duas tiras de papel preto. Nessa figrura estí no centro uma fileira de alvéolos flanqueada assim pelas duas tiras pritas, sendo o número de fileiras de sprãos igual a dois na metade superior da espiga, aumentando para trềs on quatro, na metade basal da mesma. Não aparece nenhum indício que possa ser tomado como sinal do aumentri do número de alvéolos, de modo que fica claro tratar-se, de alto a baixo. de uma só fileira de alvéolos. A presença de glumas individuais, a fornt: (los grãos e a posição dos embriōes provam que cada grão corresponde il uma espigueta. Basta para isso comparar a fig. 9,b, com a fotogratia de Cutler (10), que representa uma espiga da mesma variedude do mijtho com grãos duplos por espigueta, colocados em direções diferente. Assim, fica demonstrado que se trata do anmento do número cle espiguetas por alvéolo.

A situacão é, até certo ponto. mais clara ainda nas fotografias da espiga 33-591-42 (fig. 9,c até 1 ). Para facilitar a explicação, quebraum a espiga em três partes. A vista lateral dos dois têrços superiores (fig. $9 . i$ mostra claramente a regularidade e a saliência das fileiras. $\boldsymbol{A}$ linha pretit no centro acentua a separação das fileiras de alvéolos. A vista transversid ? (fig. 9,c e 9,d) mostra a forma pentagonal da ráquis e os triângulk brancos indicam a separação dos dinco pares de fileiras de grãos cada 211 correspondenco a um alvéolo.

Na parte basal (fig. ?,f) perke-se a regularidade das fileiras. e lid vista transversal (fig. 9,e) nota-se claramente que a ráquis continmit pentagonal. Também é relativamente fácil identificar os cinco alvéoln. indicados, como anteriormente, com pequenos triângulos brancos. Conirigando no lado direito, onde a flecha indicadora está colocada, e contan.., no selıtido do movimento do ponteiro do relógio, temos os seguintes: números de grãos por alvéolos neste corte transversal: 4-2-2-4-2. on will total de 14, em rez de 10, como na parte superior da espiga (fig. 9.. ." 9,d). As glumas individuais, a forma e posięão dos grãos, não deixam. (Ińvida alguma de que cada grã̃o corresponde a uma espigueta. 
Repetimos, mais uma vez, que constatanos na parte basal destas duas espigas um aumento do número de fileiras de grãos, os quais se tornam irregulares, sem haver aumento do numero de fileiras de alvéolos que continuam a ser regulares.

Em ambas as espigas, é claro que os grãos adicionais na base correspondem a espiguetas normais, cada uma com um só grão. Cada grão tem as suas crlumas bem destacadas, e os embriões ocupam a posição nor. mal. virados para a ponta da espiga. Não se pode tratar assim de um desenvolvimento da flor estéril de cada espigueta, como nos casos descritos por Cutler (10), para a mesma variedade de milho, onde os embriões estão em parte virados para a base da espiga. Resta, dêste modo, como única outra explicação, a hipótese de que o número de espiguetas foi aumentado para três ou quatro por alvéolos do mesmo modo como foi leserito na pág. 669 para as espigas com duas fileiras de alvéoluš e eom três espiguetas por alvéolo, nos descendentes do cruzamento milho $\mathbf{x}$ teosinto.

\section{c) Conclusão}

Desmonstramos, que: 1) em espigas pode haver um aumento do número normal (duas) para três on quatro espiguetas por alvéolo, tanto em descendentes dos híbridos milho $\mathbf{x}$ teosinto como em espigas do milho pipoca pontudo paulista; 2) nas flechas do milho tunicata paulista podem ser encontrados freqüentemente nos alvéolos, pequenos racemos, com até, no máximo, cinco espiguetas. sendo a sua forma variável de acôrdo com o tamanho dos internódios e dos pedúnculos individuais de cacla espigneta.

Não pudemos provar que o aumento de espiguetas por alvéolo nas espigas dera também. ser interpretado como consequência do fato de que n par normal de grãos seja o resultado da redução de um pequeno racemo a apenas duas espiguetas sésseis. Mas, as diferentes observações feitas llas flechas do milho tunitaca, são bastante sugestivas, pois encontramos tôdas as fases intermediárias, entre duas ou três espiguetas sésseis até racomos com três até cinco espiguetas (fig. 4 e fig. 5 ).

\section{O aumento do número de fileiras de alvéolos}

Explicamos acima (pg. 664) que os antepassados do milho tinham niks snas inflorescências apenas duas fileiras de alvéolos, do mesmo modo como encontramos ainda hoje nos outros dois gêneros das Maydeae amevicuma, Tripsacum e Euchlacna, e que o aumento de fileiras no milho Eultivado é devido à intercalação de outras fileiras de alvéolos.

Tma reversão ao tipo hipotético primitivo foi já deserita por Tavear (19) e J Jangham (14) e ela apareceu também numa família de nosso material de milho precoce brasileiro descendente de cruzamentos entre milho precoce do Canadá, milho europeu e milho brasileiro. 
Nesta forma, a ráquis, nos dois lados expostos, tem uma superfícici. lisa e córnea, de côr branca, existinclo. en geral, uma assimetria que será dlescrita mais tarde. Os pares de grãos são colocados nos dois lado: opostos e pela sua posição alternante dão uma indicação da existência de uma filotaxia em espiral 1/2.

Porém estas espigas com apenas quatro fileiras de grãos on duas dt: alvéolos nada nos revelam sôbre a modalidade da interpolação de ontras tileiras. Material interessante neste sentido. oferecem as espigas de nu outro tipo de milho que contêm mitas fileiras de grãos na base. mas apenas quatro fileiras na ponta. Tavear (19) e Mangelsdorf and Reever (15), (pg. 26) as descreveram, e tivemos ocasião de estudar um númer" bem grande de espigas desta natureza que apareceram em três tipros dt. milho: precoce brasileiro. doce hrasileiro, obtido do cruzamento entrer milho doce norte-americano e milho duro brasileiro, e, finaluente, en descendentes do cruzamento entre milho brasileiro e teosinto.

Podia-se esperar que houvesse intercalação de novas fileiras de alvíolos em qualquer lugar da espiga; que simplesmente aparecessem novas tileiras nos lados da ráquis entre as duas já existentes, de modo que estas continuassem em linha reta descle a parte basal com muitas fileiras. até a ponta. com apenas duas fileiras. Êste não é, porém, o caso. e em tôlas estas espigas pode ser comstatada mm torção das fileiras. Não ‘. sempre fácil analisar as torçoes. mas parece cue, em geral, duas fileir de alvéolos. adjacentes na parte bakal da espjga, se separam até quit ocupem os lados opostos da ráguiin. Is outras fileiras não ficam contímuas. Estas torções são bem visíveis ha tỉig. 10. Também a fotografia reepr:duzida na fï. 93,e de Mangelsdorf and Reeves (15) mostra o unesmo fenômeno. sem que os autores tenham feito menção a êste fato.

Podemos assim ver a transformaça de uma espiga, com duas fileiras: de alvéolos, para uma outra com três, quatro ou mais fileiras.

Discutiremos, em primeiro lngar. a trausformação de duas parit quatro fileiras de alvéolos (fig. 10.a até d). A explicação torna-se mais fácil quando empregamos os desenhos esquemáticos da fig. 11.

O esquema da fig. 11.a mostra a situação inicial com a presença di ¿lois ajvéolos opostos. As duas novas fileiras são intercaladas num só laclo da espiga, entre as fileiras miginais $A$ e $B$, o que provoca $\mathrm{nm}$ desiquilíbrio e, consequientemente, uma torção das fileiras indicada pelas flechas (fig. 11,b). Em consequência disso, as fileiras originais $A$ e fi; saem da sua posicão inicial e se aproximam uma da outra. No fim resulta uma espiga simétrica com guatro fileiras equidistantes (fig. $11, d$ ).

Nimma outra série demonstramos esquemàticamente a passagem di* duas para três fileiras de alvéolos (tíg. 11, a, e, e). Partindo de novo de uma espiga com duas fileiras opostas (fig. 11,a) constatamos a intercalação de uma nova fileira (fig. 11.(:), o que prornca torções até que os alvíolos ficam de novo equidistautes (fig. 11,e).

Notamos sempre uma diferença entre as espig̨as de três e de quatro lileinas de alvéolos. Nestas niltimas. as torções das fileiras se limitam à 
região da transição, mas nas primeiras atingem tôda a espig̣a. É isso. aliás, um fato geral, e, sempre, quando encontramos espigas com :? ou 6 fileiras de grãos, correspondentes a três fileiras de alvéolos, a espiọs inteira é torcida, para a direita ou para a esquerda, em todo o seu comprimento. Esta diferença de extensão da zona torcida é bem visível nas três espigas reproduzidas na fig. 10. Ela é também indicada nos diagramas da fig. 11,e e fig. 11,e. Não poderemos, porém, oferecer qualquer explieação para esta diferença, nem sôbre o desiquilíbrio geral nas espigas com três fileiras de alvéolos.

As três espigas escolhidas, reprodnzidas na fig. 10, são tôdas descendentes do cruzamento $Z e a \times$ Euchlncna, e nelas se torna ainda mais fácil identificar os alvéolos pelo desenvolvimento das tapas com as surs manchas pretas.

As fig. 10,a e 10,b representam dois aspectos da espiga 16-407-4t com quatro fileiras de alvéolos na base e duas no último têrẹo. A fig. 10,b prova que quatro fileiras de grãos, isto é, duas de alvéolos, continuam da base até a ponta, com apenas ligeiras torçoes entre o primeiro e sesundo têrço da espiga. A fig. 10,a, por outro lado, mostra as outras quatro fileiras que terminam justamente na mesma altura em que notamos as torções. Estas são fracas e as fileiras na ponta da espiga estão localizadas. não nos lados, mas numa metade da ráquis, a qual é assimétric‘a.

As duas figuras seguintes, da planta 27-372-44, têm quatro fileiras de alvéolos no têrço basal da espiga e duas nos lados da l'áquis na partr restante (fig. 10,c). As torções na zona de transiẹão de um para outro arranjamento são bem visíveis no aspecto lateral, fig. 10, d.

A última espiga, 13-448-44, tinha três fileiras de alvéolos na metade basal e duas apenas na parte superior. Só nesta última parte, a qual corresponde apenas ao quarto apical, a ráquis é reta; quanto ao resto. isto é, tanto na zona da transição, como na metade basal di espiqa a torção é nítida. A situação é um ponco complicada pelo fiato de que os alvéolos, bem delimitados pelas tapas, contêm, em grancle parte. espiguetas ou três grãos maduros. Assim, o número de fileiras de grãos no quarto apical '́ de $2 \times 2=4$ até $2 \times 3=6$, e na metade basal varia entre $3 \times 2=6$ e $3 \times 3=9$ fileiras.

Is fotografias das três espigas na fig. 10 ilustram também tmo outro ponto importante. Já acentuamos, repetidamente, a nossa convieção de que na espiga de milho. uma antiga filotaxia em espiral $1 / 2$ foi alteradi pela intercalação de mais alvéolos, tomando disposição em fileiras longitudinais. Esta hipótese está apresentada esquemàticamente na fig. 12,d e fig. 12,e. Ela está, por exemplo, em contradição com uma hipótese proposta por Collins (9), que penson que a intercalação se daria pela forma ilustrada na fig. 12,f.

Na parte apical das espigas na fig. 10,a,c,f, com duas fileiras, podemos fàcilmente ver a filotaxia dos alvéolos, muito destacada pelas tapas coloridas. A espiral com 1/2 está no sentido do movimento dos ponteiros ro 
relógio na espiga 13-488-44 e em sentido contrário nas espigas 16-407-44 e 27-372-44. Na zona de transição, na qual aparecem as novas fileiras, a espiral da filotaxia torna-se obscura, mas permanece a simetria das fileiras longitudinais, mais ou menos toreidas.

\section{Conclusão}

O estudo de espigas com num número variável de fileiras de alvéolos que aparecem raramente em milho e com mais frequência nos descendentes de híbridos Zea $\times$ Euchlacna prova que o aumento do número de fileiras de alvéolos além do primitivo (dois), é devido à intercalação de novas fileiras e que, simultâneamente, a filotaxia em espiral 1/2 desaparece, ficando apenas a simetria das fileiras longitudinais, mais ou menos toreidas.

A intercalação acontece sempre num lado só da ráquis, de modo que as fileiras, inicialmente nos flancos da ráquis, ficam deslocadas para um lado da mesma, tornando-as assim vizinhas. Porisso observa-se sempre uma torção das fileiras na zona de transição do número menor para 0 número maior das fileiras.

Além desta torção, pode ser constatada uma outra em tôda a espiga ou em parte de espigas com 3 fileiras de alvéolos.

\section{Assimetria na espiga}

Em tôdas as inflorescências masculinas das Maydeae americanae encontramos uma assimetria muito pronunciada, pois as quatro fileiras de espiguetas não estão localizadas nos lados da ráquis, mas na sua superfície inferior ou ventral. A face superior ou dorsal, oposta ao eixo principal da flecha, não tem espiguetas. Nas partes femininas das inflores(ências de Tripsacum e Euchlaena, por outro lado, temos perfeita simetria e as espiguetas estão localizadas nos lados opostos da ráquis.

Em milho, quando há apenas duas fileiras de alvéolos, encontramos a mesma assimetria entre a face dorsal e ventral, semelhante à observada nos ramos laterais da flecha (fig. 10,a e b, fig. 13,a e b). E interessante notar que nestes casos a superfície da ráquis é lisa e brilhante. Os grãos. ‘) suas glumas, estão no fim de $1 \mathrm{~m}$ pequeno pedúnculo, que forma $\mathrm{um}$ ângulo reto, ou pouco agudo, con a ráquis da espiga. Assim, a situação é muito diferente daquela encontrada em Tripsacum ou Euchlaena, em que as espiguetas maduras estão encostadas à ráquis.

É também interessante notar que esta assimetria não é consequência do aparecimento de apenas quatro fileiras de grãos, distribuídos em duas fileiras de alvéolos. Nos descendentes do cruzamento milho $\mathbf{x}$ teosinto encontramos, em diferentes plantas, ambas as formas de organização: espigas simétricas com duas fileiras nos flancos da ráquis, como em Tripsacum e Euchlaena (fig. 8,e e d), e outras assimétricas, com as fileiras no lado ventral da ráquis, como em $Z c a$ (fig. $7, d$ e $e$, fig. $8, a$ e $b$ ). Assim, podemos considerar esta assimetria como um caraterístico dêste último gênero. 
Tma outra peculiaridade temos observado freqüentemente em milho tumicata. nas formas "tassel seed" e em descendentes do cruzamento Z $\leftarrow a \times$ Euchlaena: o aparecimento de espiguetas femininas ou hermafro1 litas, combinadas com espiguetas masculinas, dentro do mesmo alvéoln. A posição das espiguetas neste caso não é an acaso. Frequientemente, as espiguetas femininas ou hermafroditas formam uma fileira, e as espiyuetas masculinas uma outra. Nas flechas de tunicata (fig. 13,a) e de "tassel seed" (fig. 13,a e b) como também nas espigas do híbrido da primeira geração do eruzamento tunicata $\mathrm{x}$ teosinto, descrito por Brieger (6), (fig. 13) nota-se uma acentuada assimetria: as fileiras internas são femininas on hermafroditas, originando depois grãos maduros, e as duas tileiras externas são formadas pelas espiguetas masculinas.

$O$ fator Tu é o único que permite o aparecimento de fileiras de espiguetas masculinas nas espigas dos híbridos da primeira geração, mas nas verações posteriores a mesma peculiaridade aparece também em plantas não-tumicata, e isto em qualquer dos cruzamentos feitos entre diferentes variedades de milho e o teosinto do México ou da Guatemala. Encontramos, assim, espigas com fileiras em número maior do que 4, sendo algumas ilelas formadas por espiguetas masculinas e outras femininas. A fig. 13, $\mathrm{C}$ e a mostra uma espiga desta natureza, vista de dois ângulos diferentes. proveniente da planta 8-375-44, que pertencia a um "back cross" para 0 milho. Nesta espiga com oito fileiras, as fileiras femininas de dois alvéolos, são adjaccentes (fig. 13,d) e igualmente as fileiras masculinas (fig. 13,c).

A combinação de espiguetas masculinas e femininas no mesmo alvéolo $\therefore$ encontrada em Euchlaena, raramente na zona da transição da parte feminina para a parte masculina que, às vêzes, é formada na ponta da rspiga. Ela é mais rara ainda em Tripsacum australe em alvéolos na base cin na ponta da parte feminina das inflorescências.

lisim. parece que o aparecimento de fileiras regulares de espiguetas masculinas, ao lado das femininas, deve ser considerado como um caraterístico específico do gênero $Z e a$, do mesmo modo como também a assimetria la posição dos alvéolos atrás mencionada.

\section{A ramificação da espiga e a teoria de fusão}

Ascherson (2) formulou uma hipótese de acôrdo com a qual a espiga de milho, com oito ou mais fileiras, é o produto da fusão de várias espigas do tipo de Euchlaena com apenas duas fileiras de grãos. Um argunento decisivo contra esta idéia foi levantado por Weatherwax (20) 'lue explicou, pela primeira vez, que se deve distinguir o número de fileiras de grãos e dos alvéolos, e que por isso, a teoria de fusão, exigiria que encontrássemos nas espigas sempre um múltiplo de duas fileiras de alviolos ou quatro fileiras de grãos quando. na realidade, o número de fileiras de grãos é apenas um múltiplo de 2. Langham (14) tenton reviver a teoria da fusão, sem fazer referência ao argumento contrário aqui mencionado, baseando-se em observações por êle realizadas nos descendentes do cruzamento milho $\mathrm{x}$ teosinto. Esse autor declarou ter encontrado 
em plantas de segunda geracõa espigas que pareciam parcialmente fundidas. O amplo material que estudamos, porém. mostron que nêle não existe tal fusão.

Para poder melhor compreender a situação, parece-nos necessário explicar, em primeiro lugar, a morfologia das flechas e dos galhos fenininos em geral. Como explicamos, não existe diferença, em princínio. entre Zea e Euchlaena. sendo em Tripsacm. (6) a organizasão mai primitiva.

Em Tripsacum anstrale tôdas as inflorescências, terminais e laterais. têm a mesma estrutura [fotografias em Brieger (6)]. O eixo principal forma, na filotaxia 1/2. alvéolos com espiguetas femininas na parte basal e masculinas na parte apical. $\mathrm{Na}$ base encontram-se, no lugar de alguns alvéolos, ramos secundários com a mesma organização. Nunca apareceram ramos terciários. Os primeiros internódios abaixo destas inflorescển:ias. ×ão, em geral, eurtos durante a antesis, mas se tornam depois longris sem. contudo, produzir galhos.

Pelo menos durante a fase feminina da abertura das flores temos as bases das inflorescências parcialmente cobertas pelas fôlhas dos nós. Istu pode ser considerado a primeira fase da transformação dessas fôlhas em palhas.

Em Euchlaena e Zea devemos distinguir as inflorescências teminais e laterais que, à primeira vista, parecem muito diferentes.

Nas flechas, temos um eixo principal que pode ter duas filas de alvéolos com filotaxia $1 / 2$ (Euchlacua) ou numerosas fileiras (Zea), ambos formando na sua base numerosos ramos em verticilos com apenas duas fileiras de alvéolos.

Abaixo dêste conjunto segne um número variável de fôlhas que nåo produzem galhos laterais. En flechas de milho tunicata observamos a sua transformação parcial em palhas. sendo a bainha bem desenvolvida e a lâmina foliar reduzida (Brieger 5, fig. 3).

Assim, temos que notar uma só diferenga entre êstes dois gêner's t Tripsacum : a organização de ramos em verticilos ou em posição alternada na base do eixo principal, o qual existe, a nosso ver, nos três gêneros. apesar de que Mangelsdorf and Reeves (15, pg. 205) acham que o eixo central falta sempre em Tripsucum a em Euchlicna. Em todos tress gêneros notamos o aparecimento de nós estéreis abaixo da inflorescência mascullina como um passo de transformação das fôlhas correspondentes em palhat.

A estrutura dos galhos laterais parece bastante diferente em $Z \in a$ e em Euchlaena, porém estas diferenças desaparecem completamente numa inspeção detalhada (6). Nas figuras 14 e 15 reproduzimos quatro galhs. desfolhados, de descendentes do crmamento milho $x$ teosinto. T'emos uma inflorescência terminal que pode ser uma simples espiga (fig. 15. b) 01 , is vêzes, aincla uma espiga ramificada (fig. 14) ou uma flecha normal (fig. 15, a). Esta inflorescência que chamamos: terminal-lateral de 1." orrlem. ó seguidla por alguns nós que não produzem galhos laterais 's. 
finalmente, na base dêste ramo de 1." ordem, temos outros nós que produzem ramos de 2.a ordem. Nestas pode-se repetir ; mesmo processo de ramificação: uma inflorescência terminal-lateral da $2 .^{a}$ ordem, seguida jor nós estéreis e, na base, ramos da $3 .^{a}$ ordem. Nas fotografias (fig. 14.a e b), êstes últimos, por sua vez, repetem o processo de ramificação em inflorescências terminais-laterais da $3 .^{a}$ ordem e ramos, na base, da 4." ordem.

Assim, temos uma série de ramificações terminando cada vez em uma inflorescência, podendo apresentar, na sua base, número variável de novos ramos. Cacla inflorescência assim. é terminal em relação a um ramo, digamos de ordem $(n+l)$, e ao mesmo t'mpo lateral de outro ramo. de ordem (n). Denominaremos, então, a infloressêneia terminal de um galho da ordem $n+1$ que seja bem desenvolvido com laterais de ordem $(n+2)$ na sua base: inflorescência terminal-lateral da ordem $\mathbf{n}+$ 1. Quando, porém, o gallıo é reduzido pràticamente à sua inflorescência terminal e mais alguns nós com fôlhas apenas, a denominação será apenas: lateraí em relação ao ramo da ordem anterior (n).

E muito importante distinguir os dois grupos de palhas em cada gatho: a) pallas imediatamente abaixo de cada inflorescência terminal, as quais sempre são estéreis, sem outra inflorescência na sua axila, servindo apenas como envólucero da infloreseência terminal; b) palhas nas bases (lo galho que apresentam nas suas axilas ramos de ordem superior, as chais iısim são órgãus protetores de tôdas as inflorescências.

Todos êstes pontos são bem visíveis nas fig. 15, a e 15, b. Em baixı da inflorescência terminal-lateral da ordem n +1 , que é uma flecha na fig. 15, a e uma espiga na fig. 15, b. temos, respectivamente, 3 e 4 nos stim ramificações, portadoras de palhas individuais. Os dois nós basais têm ramos da ordem $(n+2)$ nas axilas de suas palhas. Nos nós basais temos um ramo $(n+2)$ como uma espiga terminal, seguida por 3 nós sem novos ramos axilares, isto é, com palluas inclividuais, e depois um (fig. 15, a) ou dois (fig. 15, b) nós com um galho axilar da ordem $(n+3)$ formado por uma espiga e alguns nós estéreis com as suas palhas individuais. O segundo nó dla base do galho principal tem o sell galho da ordem (n+2) na axila da pallha ê êle repete o mesmo processo: espiga teruminl, nós rstéreis com palluas inclividuais, o dolis nós basais (fig. 15, a) oll im nó (fig. 15, b) com ramos da ordem $(n+3)$. 0 galho $(n+3)$ tem a slla espign terminal. os nós estéreis e, às vêzes, mais uma espiga lateral no nó hasal. a qual corresponde a um galho de ordem $(\mathrm{n}+4)$.

A diferença entre milho e teosinto consiste apenas no desenvolvimento (las inflorescências de ordem superior.

Em $Z e a$ desenvolve-se, em geral, apenas a infloreseência terminallateral da primeira ordem, ficando tôclas as palhas estéreis. Fm galhos ramificados (compare a fotografia em Brieger $(6$, fig. $3 \mathrm{~A}$ ) se desenrolvem também as inflorescências terminais-laterais da segunda orden. e tems. então, dois tipos de palhas: as pallass internas e estéreis, que protegem cada uma das espiqus individualmente. e as palhas externas e férteis, que 
protegem o conjunto das espigas. Lina vez que os galhos da segunda crdem produzem apenas uma espiga terminal-lateral da segunda ordem. falamos em geral apenas da espiga terminal e das espigas laterais, referindo-se estas denominações à sua posição no ramo de primeira ordem.

Em Euchlaena, por outro lado, as inflorescências laterais de ordem superior são, em geral, muito ben desenvolvidas, formando grupos on "clusters" de espigas individuais. com as palhas individuais de cads espiga, on internas, e as palhas externas do conjunto. Freqüentemente, " ramo da primeira ordem é bastante longo e as fôlhas que correspondem ìs palhas externas e férteis têm desenvolvimento quase normal, sendo apenas as bainhas mais largas e as lâminas foliares um pouco menores do que nas fôlhas normais, protegendo $\mathrm{um}$ sistema de galhos de ordem superior, representado por um conjunto de espigas.

Apresentamos as principais diferenças no esquema abaixo:

\begin{tabular}{|c|c|c|c|}
\hline Ramo da 1.a ordem & $Z e \cdot a$ & Euchlcena & Tripsacum \\
\hline Inflorescêneia terminal & espigil & $\begin{array}{l}\text { geralmente fle- } \\
\text { cha }\end{array}$ & mistas \\
\hline Tuternódios lastéreis & curtos & $\begin{array}{l}\text { freqüentemente } \\
\text { longos }\end{array}$ & longos \\
\hline $\begin{array}{l}\text { Fothas descurolvidas como: } \\
\text { Famos te' ordem superior }\end{array}$ & Ialhas & fôlhas & fôlhas \\
\hline Ta $2 .^{a}$ orden & $\begin{array}{l}\text { espigas secunciá- } \\
\text { rias laterais }\end{array}$ & $\left\{\begin{array}{l}\text { formando con- } \\
\text { junto de espi- } \\
\text { gas com inter- } \\
\text { nódios indivi- } \\
\text { duais bastante } \\
\text { curtos ("elus- } \\
\text { ters") }\end{array}\right.$ & $\begin{array}{l}\text { tôdus iguais ao } \\
\text { ramo da } 1 .{ }^{\mathrm{a}} \\
\text { ordem. }\end{array}$ \\
\hline De ordem superior & ausentes & & \\
\hline
\end{tabular}

Assim, está bastante claro que o plano básico da ramificação nos dois primeiros gêneros é idêntico. sendo as diferenças apenas de ordem secundária e quantitativa e que a diferença entre êstes e o terceiro, apesar le mais pronunciada, é também essencialmente de natureza quantitativa.

Para completar a descrição, devemos ainda mencionar uma correlação fisiológica muito interessante. Nas inflorescências laterais dos descendentes do híbrido milho $x$ teosinto nota-se, com frequência, uma diferença entre o número de fileiras. As inflorescências terminais-laterais da primeira e, às vêzes, da segunda ordem têm um número de fileiras maior do que 2, quando as espigas de ordem superior têm apeısas 2 fileiras de alvéolos. 
Parece que existem, nestas relações, diferenças genéticas entre as descendentes do cruzamento citado e encontramos três tipos de plantas : indirídnos nos quais tôdas as inflorescências, de qualquer ordem, têm mais lo que duas fileiras de alvéolos (fig. 15, b), tipo $Z e a$; indivíduos com tôdas as espigas de qualquer ordem com apenas duas fileiras, tipo $E u$ "hlaena; indivíduos com a espiga terminal-lateral e a espiga terminal do walho "prophylary" contendo mais do que duas fileiras e tôdas as demais com apenas duas fileiras (fig. 15, a) tipo intermediário.

Estas variações do número de fileiras de espigas de ordem diferente complicam freqüentemente a comprovação da regra, descoberta por Janghan (14) sôbre a correlação do número de fileiras no eixo central. da flecha e nas espigas laterais em descendentes do cruzamento $Z c a \times$ Euchlaena.

Existe nos três grêneros uma profuncla diferença botânica entre a ramificação dos galhos e das suas inflorescências terminais. $\mathrm{Na}$ primeira. todos os ramos de ordem superior estão nas axilas das fôlhas, geralmente transformadas em pallias. as cuais seguem mais ou menos uma filotaxia. em espiral 1/.. De ontro lado. dentro das inflorescências, nunea encontramos fôlhas desenvolvidas; os ramos de ordem superior estão em verticilos m em espiral, sendo o conjunto. às rêzes, protegido por palhas estéreis. localizadas na base da inflorescência. A ramificacão da inflorescência é muito nítidi nas flechas, mas podemos encontrar entre a flecha ( $f i w .15$, a) (r a espiga normal (fig. 15, b), todos os estágios intermediários do espigas ramificadas.

Reproduzimos nas fiưs. 14 e 16 três inflorescências terminais-laterais da primeira ordem. tôdas ramificadas, e notamos que o esquenta (la ramificacão é o mesmo que o la flecha de Zét e de Euchluena. O eixo central se destaca por sua posição, além de ter um número mais elevado de fileiras de grãos ( 8 nos três rasos). Na sira base encontramos un verticilo de ramos em número de 2 na fiju. 14 e 6 na fig. 16. A estrutura clestas inflorescências i a mesma las espigas ramificadas, encontradas em milho brasileiro e boliviano Brieger (6) on das linhagens recessivas para o gell ramosa, as quais estudamos também em detalhe.

As fotos reproduzidas nas figuras representam, de fato, una série contínua: espigas simples (fig. 14. b) ; espigas ponco ramificadas (fip. 14, a e b); espigas muito ramificarlas Brieger (6), fig. 11; estruturas intermediárias (fig. 16) e flechas (fjg. 14, a).

Todos êstes casos são inflorescências tepminais-laterais da primeira ordem, com verticilos de ramos que numea possuem mais do que quatro liileiras de espiguetas arranjadas assimètricamente. A face dorsal dos ramos. encostada ao eixo principal. \& livre. a as quatro fileiras estäo rolocatlas na face ventral.

Existe nma diferemça entre " ângulo formado pelos ramos e o eixo rentral uas inflorescências ramificadas. Na flecha que termina o sen desenvolvimento fora de fôlhas protetoras, êste ângulo ‘. em geral, de $90^{\circ} \mathrm{em}$ 
milho, e um ponco mais fechado en teosinto. Nas espigas ramificadas. porém, os ramos estão encostados ao eixo central e paralelos a êle em “onsequnêneia da pressão exercida pelas palhas protetoras.

Estamos preparados agora para voltar à teoria da fusão pela qual s" tentou explicar o aumento do número de fileiras nas espigas de milho. A hipótese original de Ascherson (2) de uma fusão de espigas laterais de teosinto implica no desaparecimento das palhas que individualmente protegem cada espiga, fato êste numca ubservado. Seria possível admitir-se fusão de ramos de inflorescênc.ias ramificalas, pois não existem fôlhas que constituam impecilho. Mas nunn'a observamos uma tal fusão, no material bastante extenso de inflorescências ramificadas que examinamos. 1 impressão de uma "fusão". às rêzes, é causada quando, pela presș̃̃o las palhas, os ramos são comprimidos contra o eixo central, provocando una certa deslocação das fileiras. Esta impressão é mais forte ainda chi alguns descendentes do cruzamento Zea x Euchlaena, cujas inflorescêneius alpresentam sempre duas fileiras de alvéolos e nas quais apenas existem lois ramos colocados justamente nos lados do eixo central que não contêm „ruãos. Pensamos que casos desta natureza levaram Iangham (14) a reavivar a hipótese de Ascherson (2), despresando, porém, o argumento decisivo de Weatherwax, já citado, de acôrdo com o qual o número de fileiras devia ser um múltiplo de 4 em consequência da fusão de ramos individuais, com 4 fileiras de espiguetas cada um.

\section{Conclusão}

Devemos distinguir a ramificação das inẗlorescências e aqueja do conjunto dos ramos portadores das inflorescências, o qual podemos denominar nu antocládio, segundo Goebel (11).

A ramificação da inflorescência é limitada em Tripsacum australc a poucos ramos que seguem a filotaxia em espiral 1/2. Os ramos formam verticilos nas flechas de Zea $\times$ Euchlatna, como também nas espigas rami. ficadas do milho. Os ramos nunea têm mais do que duas fileiras dt. alvéolos, independente do número de fileiras do eixo central.

Em todos os três gêneros devemos incluir ainda, como parte das intilorescências, os primeiros nós imediatamente abaixo da mesma, os quais ฟที่ apresentam ramos axilares. Muiło raramente não í tão completı esta supressão dos ramos axilares em baixo da inflorescência terminal. Por exemplo, encontramos, cumo rara exceção, em milho, uma espiga lateral ua axila da prineira fôlha, abaixo da flecha.

As diferenças entre os três gêneros são apenas quantitativas. Em Tripsacum tôdas as inflorescências são iguais, sendo apenas menor a ramificação nas infloreseências de ordem superior. Em Zea e em Euchlaeñ encontramos uma relativa diferenga entre a inflorescência terminal, a flecha exclusivamente maseulina -- e as inflorescências laterais que formam um conjunto on antocládio. ('om a mesma organização básica : em baixo da inflorescêncir terminal-lateral temos algumas fôlhas ou palhas 
estéreis e ontras mais para a base, com novos ramos e inflorescências nas suas axilas.

A diferença entre milho e teosinto é também qualitativa. Em milho se desenvolve geralmente apenas uma espiga, terminal para os ramos da primeira ordem e lateral em relaşa à haste principal, ficando tôdas as pathas estéreis. Em teosinto, encontramos bem clesenvolvidas e rom internódios bastante curtos, os ramos de ordem superior, que formam os conjuntos ou "cluters" de espigas.

Com relaça ao número de fileiras nas espigas de $u m$ antocládio. axtem três tipos nos descendentes do cruzamento Zea $\mathrm{x}$ Euchlacna: $1 \mathrm{i} l \mathrm{l}$. $\mathrm{ra}$, com numerosas fileiras em tôdas as espigas; 2) tipo Euchlaena. com duas fileiras de alvéolos em tôlas as espigas; 3 ) tipo intermeAírio $10 \mathrm{~m}$ mmerosas fileiras da espiga terminal-lateral da primeira ordem e. às rềes, tambím em algumas da segunda ordem. mas com duas fileiras apenas nas demais espigas.

Nãı existe assim, uma diferença fundamental entre a estrutura da flecha e da espiga, e foram deseritos estágios intermediários em espigas ramificarlas. Apenas o ângulo dos ramos, nas últimas é diferente do ânerulo nas flechas. devido à pressão das palhas.

A hipótese de Ascherson, que tenton explicar a espiga do milho com muitas fileiras pela fusão do conjunto de espigas em teosinto, exige que desapareçam no antocládio, tôdas as palhas individuais. Langham, que tentou revire a hispótese, provàvelmente, interpretou erradamente a istrutura de inflorescêneias ramificalas, que se apresentavam muito comprimidas pelas palhas. Não observamos indicaçóes de existêneia de uma fusão, mesmo parcial, em descendentes do cruzameuto Zea x Euchloena.

Fica ainfla como forte objeção, o arormento de Weatherwas, le acordo com a qual a hipótese da fusão exige que o número de fileiras de alvíolos xaja um míltiplo de e e aquềe dos wrãos um máltiplo de $t$.

\section{DISCYSSTO}

\section{Recapitulação dos principais resultados}

Antes de entrarmos numa disoussão mais gelal, achamos onveniente reunir os resultados das nossas observaçoes relatadas nos capítulos anteriores.

a Flores - - Normalmente unissexnais, mas encontramos flores hermatroditas perfeitas.

b) Espignetas - Normalmente biflorais, sendo ambas as flores fenteis quando matsculinas, on apenas una fértil. - a superios, feminina -a a untra, inferior, abortiva. Encontramos espiguetas bem desenvolvidas wm 1 at: : flopes, femininas ou hermafroditas num total de ate 5 flores, tintas sempre incluílas num úmico par de glumas. 
c) Alvéolos - São cavidades onde se alojam as espiguetas na ráquís. ('ujos bordos são salientes, constituindo as "tapas", fortemente desenvolvidas em Tripsacum e Euchlaenu e pequenas em Zea. Cada alvéolo tem normalmente nestes três gêneros, 2 espiguetas, exceto nas partes feminiıa: das inflorescências dos dois primeiros gêneros que apresentam una sí espigueta. Achamos material sufjeiente provando a hipótese de Collin(9), de acôrdo com a qual havia, originalmente, em cada alvéolo um pre(uneno ramo com um número variável de espiguetas em filotaxia de 1 . Encontramos, nos alvéolos de flechas, pequenos ramos com até 5 espigueta: biflorais on multiflorais, às vêzes com pedúnculos individuais e com internódios irregularmente encurtados. 0 múmero de espiguetas, o compriment." clos seus pedúneulos e dos internódins determinam os arranjamentos maivariados. Em espigas observamos o apalecimento de três on ati de quatı: espiguetas sésseis por alvéolo.

d) Número de filerias de alvéolos - $\mathrm{O}$ número básico de alvéo!n i de dois, com uma filotaxia em espiral 1/2, nas inflorescências de Trìsacum e Euchlacua e nos ramos da flecha do nilho. Explicamos o atumento (las tileiras, nas espigas e no eixo central da flecha do milho, pela interealação de novas fileiras havendo substituição simultânea da filotaxia $\mathrm{cm}$ espiral por uma disposição en fileiras longitudinais (Brieger 4 e 6 ).

$\Lambda$ presentamos a prova desta hipótese com enpigas de duas fileiras na ponta e três on quatro fỉleiras na base. Na zona de transição elas apresentam torecões $e$ as duas fileiras originais se aproximam num lado da ráquis. aparecendo ao mesmo tempo, no lado oposto. as novas fileiras.

Em espigas que possuem leês fileiras constatamos sempre forte torọni. lestas e da rácuijs.

e) Assimetria na inflorescência - Nas partes masculinas, com dua fileiras de alvéolos, pôde ser constatada assimetria. Os alvéolos năo estão colocados nos flancos, e sim na face ventral da ráquis. Nas partes femininas de Euchlaena e Tripsacum os alvéolos estão nos flancos da ráquin. Apresentamos provas de que, em Kea, há forte assimetria com a tendêneì de formar expiguetas masculinas nas fileiras externas e espignetas femininas ou hermafroditas nas fileiras internas dos alvéolos.

f) Ramificação -- Um estudo detalhado e comparativo provat qute ¿ essencialmente a mesna nos trề gêneros das Mydeae americaucue, deven‘lo-se distinguir a ramificação das próprias inflorescências e a dos antocládios, isto é, do conjunto de ramos portadores de inflorescências.

A ramificação consiste na formação de ramos na parte basal da inflorescência sem a formacọo das respectivas fôlhas: em Tripsucum numi filotaxia em espiral 1/2; nus gêneros Luchlaena e Zea, em verticilos.

A ramificação do antocládio nos dois ńltimos gêneros obedece. ent linhas gerais, ao seguinte esquema: a inflorescência terminal, xamificata n $\mathrm{na} 0$, masculina, feminina on ainda mista, apresenta em continuaçăr alguns nós estéreis, (oon fôlhas on palhas sem galhos axilares desenrolvidos, e depois, nós com fôlhas ou palhas, portadores de gallus laterais 
de ordem superior que repetem, por sta vez, o mesmo esquema de ramificação. Em $Z$ ea desenvolve-se apenas uma infllorescência terminal-lateral como simples espiga lateral, on ainda se desenvolvem, às rêzes, também espigas terminais-laterais da segunda ordem. Em Euchlaena são, an contrário, as espigas da segunda, tereeira e quarta ordem que formam os conjuntos de espigas, cujos internódios são todos muito encurtados.

Devemos distinguir dois tipos de palhas: estéreis, logo em baixo de eada inflorescência, protegendo-as individualmente; e palhas férteis, tendo os antocládios de ordem superior em suas axilas, protegendo ao mesmr tempo todo o conjunto.

Discutiremos agora êstes resultaclos sob três aspectos diferentes: em relação à genética; a importância para o problema de origem do milho. e. finalmente, encarando os problemas gerais da teoria de evolucão.

\section{A base genética das variações ohservadas}

Grande número das variagoes deseritas foram observadas em plantas. heterozigotas para o gen tumicata Tu. No material com o qual iniciamos êstes estudos, em 1937, raramente apareceram flores femininas ou hermafroditas nas flechas dos heterozigotos Tutu. Porém, depois de selecionar para 1 maior múmero cle grãos na flecha, a partir de 1938, elas não só se tornaram mais freqü̈utes, uas, tumbém, mais regulares, perdenclo assim o aspecto de uma anormalidade. Nas formas mais extremas até hoje alcan(:allas, as peculiaridades deseritas dependen, em primeiro lugar, da presenç do gen dominante $\mathbf{T u}$, e, em segundo lugar, de um número näu leterminado de gens modificadores.

A procedência ilestes modificadores não porle sẹ indicada ; êles nãun existiam nas linhagens iniciais de Tunicata. Para a manutenção dessas linhagens, foi necessário uruzálas visando eliminar o efeito muito forte clo "inbreeding", introduzindo-se muitos modificadores de milho indígenla sul-americano. Cruzando depois os descendentes. já selecionados para a intensificação da fertilidade nas flechas, com linhagens do nosso milhu: doce brasileiro, observou-se ainda maior intensificação dos referidos caraterísticos. Fiste milho doce é nun produto selecionado do cruzamento de linhagens norte-americanas e canadenses ("Golden Bantan" e derirados:. linhagem européia ("Tirol") e milhos brasileiros ("Catêto fino"), exec!ntacio para o estuclo cla ligação genética entre os gens Tu (tunicata) e su (doce) Brieger, (7). Assim demonstramos que os gens modificadores provieram de rariedades de milho onde estavam inativos, e nos quais não existia o gen determinador Tu.

Neste material, as particularidacles descritas foram observadas apenas nas flechas. As espigas, quando leseuvolvidas, eram perfeitamente normais. com fileiras bem regulares e sem flores masculinas. Quando as flechas eram muito cheias de grãos, as espigas tinham seu desenvolvimento apenas paralisado, sem alteração alg̣ma da sua estrutura. É muito interessante notal que foi necessúlia a introdnçãao de outros gens modifica- 
lores, desta vez derivados de Euchlame mexicana, para fazer apareder idênticas rariagõos nas espigas.

Os híbridos da primeira geração dos cruzamentos Zea x Euchlacna possuiam, assim, além do gen $\mathbf{T u}$, tanto os modificadores acumulados na seleção anterior em milho, rono tambím aquêles da espécie selvagem Euchlucua mexicane. As suas flechas eram completamente normais nos cruzamentos com o teosinto de Guatemala, não mostrando efeito algum do gen Tu. Elas tinham nos eruzamentos com teosinto do México, as glumas aumentadas em tamanho e sem outras transformações. Nas espigas de todos os híbridos era notível o aparecimento de flores hermafroditas e o arranjo assinetrico das espignetas femininas on hermafroditas em fileiras internas e das espiguetas masonlinas em tileiras externas.

Assim, parecía-nos que muitas clas particularidades, para se manifestarem, precisavam da presenga do gen dominante $\mathbf{T u}$, e de um conjunto de modificadores, provenientes de outras linhagens de milho ou de teosinto, os quais antes nunca foram capazos de determinar caraterísticos fenotípieos, por serem as linhagens de constituição homozigota tutu.

É interessante notar, por outro lado, que também o gen determinador Tu nem sempre é indispensável, e pole ser substituílo, ou por ontros determinadores, ou, simplesmente, por certos conjuntos de modificadores.

São bem conhecidos, em milho, outros gens que provocam também anormalidades semelhantes, tais como: flores hermafroditas; assimetria das fileiras nos alvéolos, com una espigueta maseulina e ontra femininh ou hermafroditas; aumento do número de espiguetas por alvíolo ou a sua substitujȩão por pequenos ramos e desenvolvimento de ambas as flores femininas da espigueta. Citaremos, em seguida, alguns casos por nós estudados.

O gen Tassel-seed (Ts5), um fator dominante no uromossômio IV. vausa, na flecha, o aparecimento de flores femininas on hermafroditas. além de espiguetas masenlinas rom assimetria no arranjanento das fileiras (fig. 13,b).

Cutler (10) desereveu em milho sul-americano vários casos de desenrolvimento de ambas as flores das espiguetas femininas, particularidade também conhecida do milho doce "Conntry Gentleman" e que, neste caso. $\therefore$ causado principalmente pelos dois gens recessivos pil e pi2 (Huelsen and Gillis, 12 ).

É bem conhecido que muitas das formas recessivas anãs (existem no mínimo sete gens d1, d2, ete, localizadas em diferentes cromossômios) possuem flores hermafroditas nas espigas.

O gen recessivo ramosa ( $r a 1$ ) causa freqüentemente na espiga a substituição de espiguetas por pequenos racemos. Observa-se comumente assimetria nos ramos da espiga com a formaça de fileiras ventrais de espiguetas femininas sésseis, e de fileiras laterais de espiguetas peduncnlatlas, mas completamente estéreis. 
Não nos referimos ainda aos efeitos citados no início desta diseussão nos itens a e f ( $p g$. 682). Parece que o gen Tu tem apenas um efeito muito traco neste sentido, ou nenhum efeito. Espigas ramificadas típicas não raramente aparecem nos homozigotos para o gen ramosa (ra 1).

Fica, assim, demonstrado que muitas mutações de gens do milho Tomméstico provocam. em parte e sem contudo ter ação tão ampla e-variada. alteracōes semelhantes àquelas determinadas pelo gen tunicata, que deve ser considerado, não um novo mụtante, mas um gen selvagem remanescente.

A análise detalhada dos híbridos de milho não tunicata, de consitituição tutu. com teosinto, provou que em parte o gen $\mathbf{T u}$ é até dispensável. $\Lambda \mathrm{s}$ mesmas peculiaridades aparecem parcialmente com a segregação dos gens modificadores e com a substituição dos gens de milho, acumulados durante a domesticação, pelos modificadores selvagens do teosinto, gens que isoladamente não têm efeito decisivo, mas que agindo agora em novas combinações provocam efeitos semelhantes aos do gen Tu.

Assim não pode haver dúvida de que o reajustamento dos modificadores no cruzamento Zea $\mathrm{x}$ Euchlacna pode também ser responsável em grande escala, pelo aparecimento das pectuliaridades enumeradas no início (le capitulo. Êste efeito de introdução de gens de Euchlaena pode ser explicado por dois modos. Podemos supor que se trata simplesmente da substituição de gens de domesticação de milho, por gens selvagens, os quais podíamos chamar: "wild type modifiers". Também é, "a priori", possivel que se trate de introdução de caracteres do próprio teosinto. Mas esta possibilidade deve ser excluída desile logo, visto que não existe a mínima indicação da presença dos caracteres descritos nas inflorescências io teosinto puro. Evidentemente se trata de caracteres do milho que aparecem pela ação de vários mecanismos genéticos on combinações de gens.

\section{Conclusão}

A situação parece assim talve $\%$ um pouco confusa, especialmente para técnicoss sem experiência na análise genética experimental de caracteres complexos e quantitativos. Constatamos que os mesmos efeitos fenotípicos podem ser provocados: a) por gens mutados do milho; b) pelo gen Tunirata - tolos êles em combınação com conjuntos especialmente selecionados ile modificallores - ou, ainda, c) por complexos muito especiais e escolhiclos de gens modificadores, e sem a presença de gens mutados especiais.

\section{A natureza do milho selvagem}

A nossa hipótese (Brieger. 6) sôbre a origem do milho pode ser reximida da forma seguinte:

(1) milho eultivado descende de um capim selvagem com espiga muito simples, tendo 2 fileiras de alvéolos, cada $11 \mathrm{~m}$ com dois pares de espigulutas. Os grãos, como em milho tunicata, seriam protegidos por suas grlumas longas, mais ou menos córneas e pontudas. Quando maduras, as

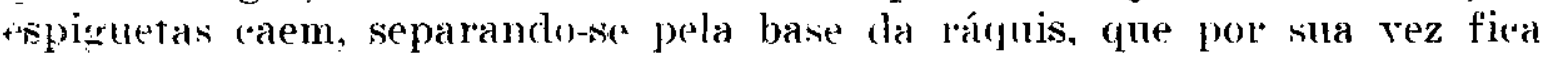
jutal.ta. 
O primeiro passo, anterior à domesticaugão, devia ter sido um cruzia mento com uma espécie de Tripsacum. Este gênero, como aliás tambéu Euchlaena, tem os gens tutu, e, porisso, glumas menores; possui ainda on grãos protegidos pelas "tapas", crescimentos laterais da ráquis. Quand. madura, a ráquis se parte, separando-se assim cala nó contendo mm si grão. Em todos os gêneros, inclusive o milho selvagem. Temos uma tilutaxia em espiral $1 / 2$ nas inflorescências. Nos descendentes do híbrid" deviam ter apareeido várias recombinasoes dos gens de ambos os pais. A combinação de geus do milho que detrminam a formação de tapas muito pequenas com a do gen tu de Tripsacum, eausa o aparecimento de grãu guase nus. A supressão da fragilidade da ráquis pelos gens de milho, " da formação da camada de separaça na base das espignetas, pelos gents de Tripsacum, resulton no aparedimento de espigas que permaneceran: inteiras quando maduras. Estas (•ombinacoes fomeciam o material inicial. com o qual os índios começaram o seu trabalho de melhoramento.

Neste cruzamento havia, rouno atontece com frequência em cruzamentos interespecíficos on intergenéroos, uma heterósis, isto é. um anmento to vigor, e os indios, que, sabenos, eram ótimos "melhoristas", đirigian os seus esforcos no sentido de manter iste aumento de vigor. Fm consequência disso, fiearam conselvados muitos gens de ambas as espuécien. incompatíveis uns com os outros fuando homozigotos, ronstituindo mit sistema semelhante ao de gens letats e semi-letais balanceados. Êles van responsáreis pela redução do rigor no "inbreeding" do milho cultivadu. pois é difícil imaginar qualquer ontro processo de evoludgão que permita acumular um tal sistema de gens balancealos, conno já explicamos (Briegrel. 6).

De acôto com esta hipotest. alguns dos caraterísticos hereditritus d. milho selvagem foram substituidos pelos gens introduzidos no cruzanento inicial de Trigsacum e ontros pelos gens mutados que foram acmmado clurante o traballo de melhoramento executado pelos índios. Devomo-

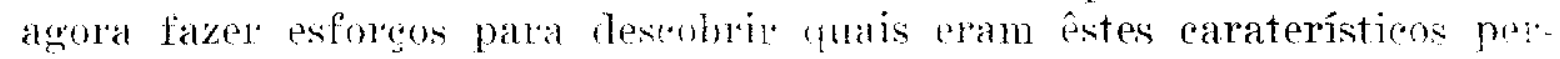
didos na evolução do milho domíntico.

Descrevemos acina rárias partirularidades observadas nos descendentes do híbrido Zea x Euchlan un. eomo: espiguetas hermafroditas " multiflorais; assimetria dos ramos da inflorescencia; combinacão reguar de una espigueta masenlina pedunoulata e outra feminina on hepmater-elita séssil em cadia alvéolo; aumento do numero de espiguetas, por alvéolo: interealação de fileiras adicionais na estrutura básica de duas fileiras de alvéolos. além de estabelecer a completa homologia la estrutura mur... lowica das inflorescências e antoclálios terminais (flecha) e laterai: (espiga). A base genética de tôdas extas rariacoes foi discutida e chegran... a conclusão de que se trata de diferentes conjuntos de modificadores qu. determinam o aparecimento dos respectivus fenótipos isoladamente, on em rombinação com certos gens determinadores, destacando-se entre êteńltimos o gen $\mathbf{T u}$.

Temos agora ainda que expliear o reaparecinento destas peculiari. dades de ontro ponto de vista. Porle tratar-sie: a) de segregados "entravi- 
gantes" no sentido do têrmo introduzido por Heribert-Nilson (16); b) de (araterísticos hipostáticos de Euchlaena ou c) de Zea selvagem.

A primeira explicação pode ser excluída, considerando a relativa frequência do aparecimento dos referidos fenótipos. A segunda hipótese também \&́ pouco provável, como já foi acima explicado, pois não existe razào para se supor que uma espécie selvagem, como Euchlaena, possua tais e tantos caracteres latentes, sem que teuham sido descritos ocasionalmente como variedades ou formas sistemáticas. Podemos, porém, acreditar que uma espécie cultivada mantivesse latentes, isto é na forma hipostática. :araterísticos da espécie original selvagem, encobertos pelos gens mutados selecionalos e acumulados durante a domesticação. Assim, consideramos, :omo mais povável, a terceira das hipóteses mencionadas.

Podemos agora constatar como proráveis caracteres de milho selvagém is seguintes:

As inflorescências eram assimétricas e tinham duas fileiras de alvéolos. uma com espiguetas pedunculadas masculinas e outra séssil hermafrodita. ou, talvez, em certas partes da planta, ambas eram masculinas. Havia sempre apenas duas fileiras de alvéolos, as quais seguiam uma filotaxia em espiral 1/2.

A forte protoginia dentro de cada inflorescência permitiu que as barhas saíssem fora das bainhas das fôlhas protetoras na fase feminina da antésis; os órorãos masculinos só mais tarde entraram em funcionamento rquando tôda a inflorescência já havia saído para fora dos órgãos protetores, pelo alongamento da parte não ramificada do galho, logo abaixo la inflorescência, da mesma forma como até certo ponto acontece aindı hoje eni Tripsacum. Neste momento os grãos passaram mais ou menos à fase leitusa e os órgãos protetores já estavam endurecidos.

As inflorescências terminais tinham eixo central e verticilos de ramo na sua base, do mesmo modo como em muitas Gramíneae. Em analogia com Tripsacum e Euchlaena podemos supor que o número dêstes ramos diminui con a ordem dos antocládios. Dêste modo, por certo, os antocládios ]e ordem superiol foram reduzidos a conjuntos de inflorescências. Talvez já havia 1 m início de uma separação paralela dos sexos com um aumento de nimero de espiguetas masculinas nas inflorescências terminais.

As espiguetas eram possivelmente multiflorais, e, neste caso, o milho selvagem nem pertencia mais ao grupo dos Andropogeneac.

$A$ isto devemos acrescentar ainda mais dois caraterísticos, já men:ionados anteriormente, Brieger (6): a) proteção dos grãos maduros pelas glumas, devido à ação do gen $\mathbf{T u}$, e b) (amada de separação na base dos rãos de expiguetas quando maduras.

Todos êstes caraterísticos foram observados em nosso material, isola،lamente ou em conjunto, de modo que já se podia até desenhar um esquema la estrutura hipotética do milbo selvagem. Temos, porém, ainda a esperança de encontrar um inclivíduo que tenha todos os caracteres essenciais rm conjunto de modo que seja possírel fotografá-lo. 


\section{O problema geral filogenético}

Mencionamos, na introdução, o problema geral filogenético das Gruminece que consiste na explicação do acúmulo de processos de reduẹão. Sôbre as causas destas reduções, a famosa especialista Agnes Arher (1) chegou a conclusões, que seguem, em tradução:

"Um resumo do que está exposto neste e nos capítulos precedentrnos conduz à conclusão de que particularidades especiais, tanto da f̂loy" típica das Gramineae como cle formas mais divergentes, parecem causadx. essencialmente por processos de reduegoes, as quais modificam $\mathrm{nm}$ tipo qllt* pode ser visto numa forma menos restrita nas Bambusaceae. Esta reduça pode ser posta frequientemente em relação aos efeitos de ajuntamento pressão durante a ontogenia. Porém, além de perdas e fusões que obviamente são correlacionadas com a pressão, nós podemos recouhecer un: número de formas de esterilidade de espiguetas e de unissexualidade on de abortos das flores pelos quais a pressão podia ser, no máximo. responsável apenas em parte. Parece claro que as Gramineae sofrem cle unid tendência, definidamente inerente, para algum grau de esterilidacle di galho reprodutivo" (pg. 206).

Destas duas causas das reduções, a primeira, a pressão sôbre os órgãuis. exercida especialmente por fôlhas protetoras que não deixam espaço livire ìs flores ou partes por elas enrolvidas, parece-nos de pouca importância. Pressão é uma fôrça que tem o efeito sempre em dois sentidos. As fôlha protetoras exercem pressão sôbre os órgãos internos e êstes, por sua ve. sôbre as fôlhas. Além disso, a redução é um fenômeno generalizado, d.. forma que, a sua causa deve ser igualmente generalizada. Não se podendo aceitar, para explicá-la, "ajuntamento" ou pressão, temos de admitir a influência de fatôres de ordem mais ampla. Finalmente, a pressão de orgãos pode provocar efeitos fenotipians, mas não pode ser responsaid por alterações genotípicas, não tenclo assim ação sôbre a erolução.

Outro fato citado por Agnes Arber, e evidentemente mais importanu. é o chamado por esta autora "the definite inherent trent". $\mathrm{E}$ neste mesmo sentido que usamos, às vêzes, o têrmo "ortogênese" on linha contínua de evolução. Mas não devemos esperar ser possível arranjar todos os gyneros em sub-famílias, numa ímica série contínua de reduȩões progrisivas. Como Arber explica, com muitos exemplos, existe, nas estruturis normais cu patológicas, un! paralelismo e una repetiogão muito pronum('iada (pg. 398). Essa autora pensa que nas Gramineae aparecem tônas as tenclêncjas "which can be developed within the definite throngh elas i: frame work of the ordinal type" (pg. 4) fazendo referência $\dot{a}$ ord sn sistemática "Gramineae" no têrmo "ordinal".

() têrmo "ortogênese" acima usado, não deve ser tomado assim mıit.: literalmente. Não podemos arranjar os diferentes grupos on gêneros t? uma ou algumas séries que apresentam uma única tendência constarte. ıumma só direção, pelo acúmnlo sistemático de processos de redução ư or xãos florais. Tomando em consileração os detalhes, eucontramos parit- 
lelismos, repetições e reversões nas tendências. As séries "ortogrenéticas" são sempre abstrações que servem apenas para ilustrar qual a tendência inerente a um grupo de gêneros, não representando exatamente o curso da evolução dêstes gêneros. Mesmo as séries paleontológicas, como aquela do cavalo ou do elefante, Brieger (5, fig. 7 e 8 ), são apenas abstrações que inlicam como se processou a evolução.

Devemos agora averiguar qual o mecanismo filogenético que explica a existência destas tendências inerentes na evolução. $O$ lamarckisino naturalmente oferece, à primeira vista, a explicação, mais compreensivel, mas tôdas as experiências até hoje registadas são unânimes em provar que não existe hereditariedade de car'acteres adquiridos. Por outro iado. os pontos básicos da teoria de Darwin estão confirmados experimentaimente: existem variações hereditárias, mutações gênicas, que aparecem sem direção e que afetam o fenótipo, existindo também uma seleção natural que elimina tôdas as mutações desfavoráveis. Mas é muito difícil imaginar alguma coisa tão coordenada, como uma tendência filogenética inerente.

Explicamos em outra publicação (5), qual o mecanismo genético que permite o aparecimento de tendências filogenéticas, e o denominamos "modifier shift" ou "mudança do conjunto de modificadores". Assin, um dos fatôres mais importantes na evolução, não nos parece ser a mutação gênica inicial, mas a mudança do conjunto de modificadores, preexistentes. os quais, en combinação com o novo gen mutado, acham então um novo campo de ação fenotípica. A seleção natural age, na evolução, do mesmo modo como que a seleção dirigidla nos experimentos. A seleção dos modificadores pode produzir novos fenótipos, sem mutação, apenas pela recombinação de gens nos cruzamentos. A existência e o funcionamento dos "modifier shift" foram demonstratos em vários experimentos de seleção, dirjgidos em vários sentidos.

Por simples seleção sem aparecimento de mutaçōes, ("ouseguimos, ('m poucas gerações, em milho indigend dos "chavantes" de grãos brancos (devido à presença de um inibidor $\mathbf{C}^{\mathrm{i}}$ no cromossômio IX) obter plantas. com grãos inteiramente coloridos. intensificando-se, gradativamente, a coloração, de geração a geração. Por ontro lado, transformamos o milho "red brittle" - - uma linhagem que serve para a análise da ligação genética mo $V$ cromossômio -- em um milho com orrãos incolores. Nestes dois exemplos conseguimos apenas uma modificação da dominância on epístase, stem eausar o aparecimento de qualquer caráter novo.

Em milho tunicata paulista executamos duas séries de seleção, una para aumentar ao máximo os efeitos do gen Tu e outra para fazer desaparecer, tanto quanto possível, todo o sen efeito fenotípico Brieger (5 e 6). Referimo-nos, várias vêzes, nos capítulos anteriores dêste trabalho. a êstros experimentos, e explicamos o aparecimento de efeitos completamente noros devido à combinação do gen Tu com outros modificadores. Nestes experimentos introduzimos, por cruzamento. o gen $\mathbf{T u}$, em material que ru homozigoto tutu, e o mesmo aconteceria se houvesse uma mutação de tu 
para Tu. O essencial é que nós combinamos modificadores com novos aleles rle gens determinadores.

Assim, perece-nos estar perfeitamente demonstrado que a selecăa, artificial ou natural, dos modificadores. clepois de uma mutação on de um eruzamento, pode ser a causa do apalecimento e da intensificação de novos caraterísticos hereditários.

Apliaando êste priucípio aos processos da evolução, podemos concluir yue o desaparecimento dos caraterísticos não implica no desaparecimento também de gens responsáveis e a sua substituição por novos aleles, por mutação. Os gens apenas mudam de função ou ficam mais ou menos inativos, pela alteração provocada 10 conjunto de modificadores. Alterandose a direção da seleção natural êstes gens podem assim reaparecer com sua antiga função fenotípica, causando uma reversão filogenética, ou. entrando em novas combinações on por cruzamentos ou depois de uma mutação gênica, provocando o aparecimento de novos caraterísticos. Queremos salientar, porém, que o novo ajuste dos modificadores é um processo ıão muito lento, dirigido pela seleção, seja natural ou artificial.

As formas descritas neste trabalho oferecem mais material em apôio a esta nossa hipótese da importância dos modificadores na evolução. Aproreitamos a hipótese acima para tirar, retrospectivamente, conclusīes sôbre uma futura evolução. Ficon eridente que são inerentes ao milho as mais variadas possibilidades para uma futura evolução, sem a intervençãı de novas mutações. Em milho heterozigoto ou em híbrido milho $x$ teosinto. a seleção experimental em novo sentido, provocando um "modifier shift". permitiu o aparecimento de formas muito variadas, entre elas : espiguetas multiflorais, caraterístico de outro grupo das Gramineae, ou três espiguetas por alvéolo, caraterístico de cevada (Hordeum). O tempo e o número de gerações submetidas a esta seleção não foram ainda suficientes para fixar e homogenizar linhagens portadoras dos novos caraterísticos. ILas existem boas indicações de que esta fixação seja viável.

O caraterístico principal do método aplicado foi a mudança radical la direção da seleção. Numa espécie como o milho, que durante milhares de gerações vem sendo submetida a uma seleção visando transformar uma planta selvagem em uma planta doméstica, executamos seleção contrária aos caraterísticos de domesticação e em favor de caracteres que deverãr, lar de novo uma planta selvagem.

A. seleção natural não tem direção fixa; uma mutação pode abrir novas possibilidades e a transferência de uma espécie para nm noro ambiente ecológico pode acarretar novas exigências.

No esquema da evolução acima explicado, existe um ponto de granrle importância. Temos que aceitar a lipótese de que os gêneros de um grande grupo, como as Gramineac, contêm um grande número de gens. os quais, sem ser idênticos, prorocam ações fenotípicas semelhantes. A sua presença explica genèticamente "que nós chamamos: a tendência comum inerente ("the comum and inherent trent"). Como prova, basta lembrar 
mais uma vez que obtivemos em milho, geralmente incluído na família de Andropogoneae, formas com espiguetas multiflorais, caraterísticos de Paniceae. Assim, o "modifier shift" explica até as reversões e o paralelismo da evolução num grupo grande como as Gramineae.

\section{O C L U S OE GERAIS}

Descrevemos neste trabalho um certo número de variações da estrutura das inflorescências e das flores do milho. Como apresentamos em cada capítulo um resumo das observações efetuadas além das conclusões muito concisas no início do capítulo anterior, podemos dispensar aqui repetições desnecessárias.

Destacamos as seguintes conclusões gerais :

1) - A estrutura básica das inflorescências e antocládios, como chamamos os conjuntos de ramos portadores das inflorescências, é idêntica nos três gêneros das Mydeae americanae, sendo as diferenças essencialmente quantitativas. Devemos, porém, distinguir a ramificação das inflorescências e dos antocládios que são morfològicamente bastante diferentes.

2) - A base genética das variações descritas do milho é a seguinte: elas dependem, em milho puro, da presença de vários gens determinadores, destacando-se entre êles o gen Tu (tunicata) por sua ação fenotípica muito diversa e pleiotrópica. Estes determinadores agem sempre em conjunto com complexos de modificadores. Nos descendentes do cruzamento de Zca x Euchlaena, a presença dos determinadores se torna dispensável e o fenótipo é essencialmente determinado pelos conjuntos dos modificadores.

3) - Achamos material que comprova várias hipóteses sôbre a estrutura da espiga do milho cultivado.

a) Não pode haver a menor dúvida de que o eixo central da flecha é homólogo à espiga ramificada e que os ramos da flecha correspondem aos ramos de espigas ramificadas.

b) Demonstramos que a espigueta bifloral das Maydeae é uma estrutura reduzida e observamos espiguetas multiflorais com até três flores férteis, além de outras flores estéreis e imperfeitas.

c) Em apôio à hipótese de Collins (9) de que o par de espiguetas por alvéolo é o que resta de um pequeno ramo, observamos uma reversão à forma inicial, isto é, ramos com numerosas espiguetas.

d) Comprovamos uma nossa nova hipótese de que o aumento do número de grãos e a irregularidade das fileiras, observada às vêzes na base de espigas, são devidas não a um aumento do número de fileiras de alvéolos, mas ao aumento de dois para três, quatro, etc., do número de espiguetas por alvéolo.

e) A nossa hipótese de que o elevado número de fileiras de alvéolos é devido à intercalação de novas fileiras entre as duas fileiras do milho primitivo, e à substituição simultânea da filotaxia em espiral $1 / 2$ por uma 
simetria de fileiras longitudinais, pôde ser comprovada diretamente pela observação de espigas com duas fileiras de alvéolos apenas, na parte apical, * fileiras mais numerosas, na parte basal.

4) - Já tentamos em outros trabalhos (4 e 6) reconstruir a estrutura mais provável da espiga do milho selvagem, tendo sido agora possivel adicionar outros caracteres. Assim, não temos mais dúvida de que ela apresentava as espiguetas aos pares, arranjadas em duas fileiras longitudinais de alvéolos, obedecendo a uma filotaxia em espiral 1/2. Estas fileiras de alvéolos não estavam colocadas nos flancos opostos da ráquis, como em Euchlaena ou Tripsacum, mas estavam deslocadas para a face ventral da mesma. Das quatro fileiras de espiguetas, as duas internas eram femininas ou hermafroditas e sésseis, e as externas masculinas e peduneuladas. A protoginia muito pronunciada das flores, na mesma inflorescência, permitiu que, na fase feminina da antesis, a inflorescência permanecesse dentro das palhas, exceto as barbas; saindo as anteras mais tarde, quando as glumas já estavam endurecidas. Dêste modo, as espiguetas estavam fora das palhas na fase masculina. Possivelmente, já havia uma diferenciação no sentido de as inflorescências terminais serem ramificadas e predominantemente masculinas, e as inflorescências laterais nos ramos de ordem superior dos antocládios, não ramificadas e bissexuais.

Podemos acrescentar mais os dois caraterísticos descritos anteriormente: os grãos eram protegidos individualmente pelas glumas endurecidas e longas, devido à presença do gen Tu, e as espiguetas inteiras, quando maduras, se separavam da ráquis pela formação de uma camada de separação na sua base.

Sòmente foram eliminados êstes últimos dois caracteres pela introdução de gens de uma espécie de Tripsacum, na fase anterior à domesticação do milho; os demais caracteres primitivos se perderam pela acunıulação de gens mutados e seleção dos complexos de modificadores.

5) - Finalmente, discutimos alguns problemas da teoria da evolução. Explicamos em outro trabalho (5) como a mudança do conjunto de modificadores, causada pela seleção, pode ser responsável pelo aparecimento de séries filogenéticas. Por outro lado, a existência de tais séries ou de tendências filogenéticas, são difìcilmente explicadas pelo acúmulo de mutações gênicas, não dirigidas.

Para as Gramineae, Arber (1) demonstrou a existência de "tendências inerentes filogenéticas" e um grande paralelismo da filogenia nos diferentes grupos desta ordem de plantas.

Demonstramos que em milho, de fato, estão inerentes muitas possıbilidades filogenéticas, as quais fizemos aparecer em consequência da mudança de modificadores. Baseados nestes experimentos, explicamos assiri o mecanismo genético das tendências filogenéticas descritas por Arber.

Estas possibilidades filogenéticas que existem em milho, fazendo aparecer caraterísticos de outros genêros, permitem também formular uma hipótese genética para o paralelismo da filogenia, supondo apenas que as 
diferentes Gramineae contêm gens que, sem que sejam idênticos, poulem determinar o aparecimento de caracteres fenotípicos correspondentes e semelhantes.

\section{SUMMARY}

1) The present paper deals with variations in the structure of the inflorescences of the Maydeae Americanae, especially of the ear of Zea Mays, which came under observation during our genetical studies during the last 10 years. Care was tauken to include only such structures which were observed frequently and had in general an aspeet which could not be described as a pathological abnormality, but rather as a reversion to a phylogenetically primitive type or as a new form.

The aberrations may be summarized as follows:

a) Individual flowers. Reversion to the hermaphrodite state of the usually unisexual flowers in Maydeae were deseribed. Such flowers are however already so well known that no details need to be given.

b) Many flowered spikelets. The spikelet in all the American Maydeae are normally two flowered. In forms of tunicata, obtained by selection, spikelets were obtained with up to three perfeet flowers, all produeing well developed kernels (Fig. 4-6), with a maximum of five flowers. The structure of three-flowered spikelets is explained in the diagrams Fig. 2 and 3. Owing to the organization of the flowers, the embryos of the first and third are turned towards the base of the inflorescence and the embryo of the second flower towards its tip. The embryos in two-flowered epikelets are normally turned to the base (first flower) and to the tip (second flower). (Cutler, 10). Cases were observed of three flowered spikelets with one abortive flower, both the remaining embryos, produced by the first and third flower, turned towards the base of the infloreseence.

c) Number of spikelets per alveolus. In maize and in the male parts of the infloresences of Euchlaena and Tripsacn two spikelets are formed per alveolus, while in the female parts of the latter genera one spikelet is present, though oceasionally exceptions are found. Collins (8) explained the appearance of the double spikclet as remainder of a small spikelet branch which has been lost during evolution. The normal structure and that of a spikelet branch is shown schematically in Fig. 3, e-f.

In the tassels of several tunicata plants small and regular branches of spikelets appeared in the alveoli, their form depending upon three factors: a) number of spikelets, b) length of the internodes of the spikelet branch, e) length of the individual pedicel of each pinelet, as may be seen in the fotos of Fig. 4-5.

An increase in the number of spikelets per alveolus in the ear has been nbserved frequently in material of two sonrees: decendants of the lyybrid maize $\mathbf{x}$ teosinte : and

\section{Paulista Pointed Pop Corn.}

The descendants of the eross Zea $\mathrm{x}$ Euchlaena have very frequently only two rows of alveoli, well separated from each other. This separation is accentuated still further by the development of a sealy outgrowth from the rachis, as in Euchlacra, which limits each alveolus at its base and on both sides. The segregates may have these seales not only well developed, but they are also frequently colored, as is the cases representad, with black dots. Thus the identification of each alveolus is very easy and fig. 7 shows an ear with two rows of well defined alveoli, each with three spikelets or three mature kernels each.

The ears of Paulista Pointed Pop Corn offer excellent material since here the rows of alveoli are very clearly defined and separated by deep ridges, the double rows of kemels being very salient. The kernels correspond always, in the ears used, to single spikelets as shown by their glumes, well developed in this variety, and the position of their embryos. In Fig. 9, a, the deep ridge separating the rows of alveoli on the left and right is elearly seen as a series of black deep shadowns in the centre of the photo. In Fig. 9, be have the same ear photographed from another angle. One row of alveoli is seen in the centre, in elear contrast against two strips of black 
paper inserted in the two lateral ridges. This row of alveoli contains very clearly two rows of kernels or spikelets in its upper part and many irregular rows in the lower half showing the increase of spikelet number. Fig. 9 c-f represents another ear with five rows of alveoli, which are very distinct in the upper part of the ear. The ear was broken into three parts and the cross sections plographed. The upper two thirds with a regular row arrangement (Fig. $9 \mathrm{c}-\mathrm{d}$ ) show clearly the five rows of alveoli and the 10 rows of kernels. The lower part (Fig. 9,e) shows still the pentagonal form of the rachis and the five rows of alveoli may still be distinguished. But the increased number of spikelets, which vary from 2 to 4 , do not permit a regular arrangement of rows of kernels within the regular rows of alveoli.

The appearance of small branches in the alveoli of mutants of maize is not anything really new, but as far as $I$ know an inerease of the number of sessile spikelets in the ear from two to three which was observed in several descendants of the Zea-Euchlaena cross and its increase to three or four in the basal region of ordinary corn ears has not been registered before. The explication for this form of increase is casily to be drawn from an inspeetion of the plotos in Figs. 4 and 5 , where we find various stages in the reduction of branches with many spikelets to two, three or four sessile spikelets.

d) Number of rows of alveoli. There can be little doubt that the basie number of rows in the Maydeae Americanac is always two as shown by all inflorescences is Tripsacum and Euchlaena and by the tassel branches in maize and the branches in Zea "ramosa". The increase of rows in the car and the eentral spike of maize has been the object of a very extensive literature. Mangelsdorf and Reeves, (15), gave a very detailed review), and I explained this increase as a simple interpolation of new rows, such as occurs in succulent plants and call be casily seen for instanee in different species of Cereus. The correctness of this interpretation can be shown directly in ears of maize which have two rows at the tip and more numerous rows at the botton and which appeared in my material of Brazilian Early and Brazilian Sweet Corn, extracted from multiple crosses between Brazilian, European and North American corn, and with much more frequency among the descendants of the maize-teosinte cross. Three such cases are reproduced in Fig. 10.

The situation is represented schematically in Fig. 11. The diagram Fig. 11a represents the primitive from with two rows of alveoli, each with two rows of kernels. The interpolation of two new rows (Fig. 11b) causes a disturbance of the equilibrium which forces the two original rows to become dislocated, as shown in Fig. 11d, thus resulting finally the normal ear with four rows of alveoli or eight rows of kernels, all equally spaced. The interpolation of a single row of alveoli causes a similar disturbance (Fig. 11c) which causes distortions untill all rows are equidistant (Fig. 11e). For some reasons, still unknown, the ears remain twisted in the latter case with three rows, while in the former a twisting occurs only in the transition zone.

These drawings however are not abstractions, but represent the situation actually observed and represented by the Fig. 10, a-b e Fig. 10, $c-d$, with in increase from two to four rows and by the Fig. 10, e-f with an increase from two to three rows. The two first ears, photographed each from two different angles, show clearly that the two rows of the top region become neighbours at the botton, while the new rows are interpolated on the opposite side of the rachis. The last ear shows the permanent twist in the lower third of the ear, and it may be added that all cars, wich $I$ have observed so far, with three rows of alveoli are always twisted over their whole length.

I postulated furthermore that originally the alveoli followed an alternating spiral arrangement or a phyllotaxy of $1 / 2$, while the interpolation of new rows abolished this spiral and substituded a longitudinal row arrangement, again as in Cactaceae and other succulent forms. The fotos in Fig. 10 show that this is actually the case. The arrangcment of the alveoli in the two-rowed part of the ear follows the spiral (1/2), while the spiral is completely lost in the many rowed region. The rows may be twisted in ears with an uneven row number, but this twist has nothing to do with the original spiral of the alveoli, as may be seen clearly in Fig. 10, e and $f$. It may 
be mentioned that the situation in the latter ear is still more complieated by the fact that the alveoli contain frequently three, instead of two spikelets.

e) Asymmetry of the inflorescence. In the male inflorescences of all the Maydeae Americanae a pronounced asymmetry of the rows may be observed which are not localised on the sides of the rachis but are pushed towards its ventral surface. In the female parts of Tripsacum and Euchlaena on the other side, the spikelets are alway on oposite sides, while nothing can be said with regards to the many rowed corn ear and the central spike of the tassel. I have no doubt that the original type of maize with only two rows of alveoli was asymmetrical, which seems to be very clear when inspectionig two rowed ears or too rowed parts of ears of mutants. It is very interesting to note that there is a segregation in the descendants of the Zea-Euchlaena cross with two rowed ears, which may be symmetrical (Fig. 8, e-d) or asymmetrical (Fig. 7, Fig. 8, a-b). The symmetry is independent from the number of rows of kernels which may be either one or two per alveolus.

Besides this asymmetrical arrangement of the rows of alveolus, there may appaer in maize on asymmetry between the rows of spikelets: a regular combination of one row of sessile female and pedicelled male spikelets. Such a situation in the tassel branches of tunicata and tassel seed is shown in Fig. 13, a and b, and that of an ear with 4 rows of alveoli in Fig. 13, e e d.

1) A detailed and comparative study of the ramification of inflorescences in the three genera of Maydeae Americanae showed an extreme degree of uniformity, which apparently has not been noticed to this extent before.

The terminal inflorescence, of main shoot or branches, has essentially the same structure: there is always a central or main spike which may be branched at its base. In Tripsacum, these branches follow an alternate spiral arrangement while in the tassel of maize and teosinte and in branehed maize ears they form one or more whorls. The alveoli, even in many-rowed maize, are always arranged in two rows on all these branches. Below the inflorescence and again in all three genera there are several sterile leafs which may be more or less transformed into husks and which only very excepcionally produce branches in their axils.

The branches, produced by the lower leafs, terminate again in an inflorescence which may be branched or not, followed first by sterile leafs or husks and than by fertile leafs bearing again branches of higher order. In Tripsacum australe all branches of any order are essentially alike, except for a progressive reduction of the branching of the inflorescence. Branches of third or fourth order bear simple terminal spikes. In $Z e a$ and Euchlaena the lateral branches of main stalks form a compound which we may call with Goebel (11) an anthocladiun. Its structure is explained by the two fotos in Fig. 14 which were taken from two descendants of the icross Zea $x$ Euchlaena.

These authocladiums have a terminal inflorescence which may be a simple ear (Fig. 1;b), a slighty (Fig. 14) or an extremely branched inflorescence, carrying male and female spikelets on its four rowed branches (Fig. 16) or which may finally be a normal tassel (Fig. 15a). There follow a few sterile leafs, forming the individual husks of the terminal inflorescence and than fertile leafs or husks which are protecting the rest of the anthoeladia. In their axils there are again branches $(n+2)$ with terminal inflorescences, always represented by an ear, protected by their indivicual and sterile husks, followed by otler husks which protect both the branein ( $n+2$ ) and its higher derivatives. The authocladium of Fig. 15 earries branches up to those of order $(n+4)$.

The difference of $Z e a$ and Euchlaena is only of quantitative nature. In Zea generally there is developed only the terminal ear of the lateral branch of order $(n+1)$ and only rarely some ears, terminal of the order $(n+2)$ which may be called also lateral to the branch $(n+1)$, as shown by Brieger (6). All leafs are transformed generally into husks. In Euchlaena, on the other side, the terminal inflorescence of order $(n+1)$ is generally a tassel and this branch earries almost normal leafs. Those of the lower nodes produce in their axils the antocladia, with the branches $(n+2)$, $(n+3)$, ete. which together form the cluster of cars. Every ear as a terminal 
inflorescence of its branch is protected by individual husks, besides the basal husks, as described above, which protect each branch and all its laterals of hingher order.

In the descendants of the Zea-Euchlaena corn an interesting detail was found, and the following three types were established: a) maize type derivatives where all ixflorescences had a high number of rows of alveoli. b) teosinte--type derivatives where all inflorescences had only two rows of alveoli, and $c$ ) intermediate derivatives where only the main terminal inflorescence of order $(n+1)$ was many rowed and sometines also inflorescences of order $(n+2)$, especially the prophyllary branch, all other infloreseences beeing two-rowed. These complicated relations obscure frequently the rule established by Langham (14) about the correlation between row number in the lateral ear and the central spike of the tassel.

These observations lead to a revision of the old hypothesis of Ascherson (2) about the origim of the many-rowed ear by a fusion of the ear clusters in Euchlaena. Weatherwax (20) has given already one very decisive argument against this hypothesis, explaining that a fusion must result in the forming of an ear where the number of kernel rows should be a multiple of four and that of alveoli a multiple of 2 . Another diffieulty is that the original hypothesis would require a complete disappearance of all individual husks, and no signe of this has ever been observed. Iangham (14) who tried to revive the hypothesis was probably mistaken, interpreting as a fusion, structures which were only branchad terminal ears, which its branches forced almost into the main spike by the pressure of the involving glumes.

2) After describing these deviations form the normal type of maize ears and inflorescences, its genetical basis was discussed. First it was thought that definite genes were involved, such a the ramosa-gen, the dwarf-factors which frequently cause the appearance of perfect bisexual flowers, the tassel seed factors, etc, and finally the tunicat factor which has the most extreme range of phaenotypice effects as ahown in several previous publieations (Brieger, $4,5,6,7$ ). Buth thel studies of tunieata maize had already shown that the modifier gens are at least as important as the main determing gen. By selection I succeded to increase to a extreme degree their ef fe'ts on the tassel. Croasing these derivations of Paulista Podi Corn to Euchlaena a complete change of the situation was brought about. The effects on the tassel disappeared immediately in the Fl with Guatemala teosinte while in those with Mexico teosinte the glumes in the tassel remained shighthy enlarged. On the other side, changes occured in the ear structure unknown to pure maize, as illustratad by Brieger (6). The descendants of these crosses showed that the specific determiner genes of maize are dispensable and that a recombination of $Z e a$ and Euchlaene madifiers a is completely sufficient.

I described in the present paper only variations in the structure of inflorescence which appeared both in degcendants of the hybrids and in pure maize. No similar vairiations hare been observed in Euchlaena or in Tripsacum, the thind species of the group. We may thus conelude that these variations were all inverent to corn, hypostatic recessive to the many gens accumulated during domestication and reappearing again after the substitution of these genes of domestication by the wild type modifiers derived from Euchaena.

3) The final conelusions of the preceding chapter leads us to a reconsideration of our concepts about the structure of the wild ancector. I discussed the problem in several previous publications $(4,6)$ and shall repeat the main conelusions without entering into a detailed discussion. Cultivated maize is derived from a wild grass which had simple ears with two rows of alveoli, grains protected by large, pointed and horny glumes, due to the presence of the gene $\mathbf{T u}$, and an abscission layer at the base of each spikelet. Thus the grains fell off when mature with their protective glumes, separated from the rachis which was thin, flexible and not brittle. This grass happened to cross with some form of Tripsacum whith its grains mainly protected by special scales, having relatively small glumes due to the presence of the gen tu. The rachis of this species is always horny, brittle and breaks on maturity into parts at each node. In natural descendants of these hybrids segregates appeared which were homozygous tutu and thus had small glumes, while maize factors suppresed the deve- 
lopment of the scales. Both abscissions layers were mutually supressed, that at the base of the spikelet from maize and the other, from Tripsacum at each node of the rachis.

We now may add more informations about the probable structure of the original inflorescences. The lateral inflorescences were asymmetrical and contained in each of the two rows of alveoli one row of sessile femalle or hemaphroditic spikelets and another row of pedicelled male spikelets. The very pronounced protogyny of flowers $^{\prime}$ in the same inflorescence permitted that the infloreseences remained within the husks or within the sheaths of only slightly altered leaves during the female phase, emitting only the silks. During the following male phase, the inflorescences were pushed out of the glumes by the lengthening of the internodes, thus permitting the shedding of the poillin, : whi'e at the isame time the glumes of the already fertilized fomale flowers had becone already big and horny, protecting the kernels in the milkystage.

The terminal inflorescences may have been branched with one or more whorls of branches at its base, and the number of branches was less in the lateral inflorescences of higher order. There may have been already some more pronounced differentiation of terminal and lateral inflorescences with a predominance in the formor of male spikelets. There exists a possibility that the spikelets were many flowered and thus this wild grass did not really belong to the Andropogoneae, as already supposed by Harshberger.

It seems now possible to make a drawing of this hypothetical wild type, but I think it even possible to find eventually among the descendants of the maize-teosinte cross most of these characters in combination, thus permitting to take a photograph.

4) The results described opened the way for drawing still more general conclusions about the mechanism of evolution, by combining two sets of facts with the new results obtained.

In the first place, we may mention the conclusions at which Agnes Arber (1) arrived in her detailed study on the evolution of the order Gramineae. She stated that there exists a) "inherent phylogenetical trend" for reduction and sterility in inflorescence and flowers, and b) a large measure of repetition and of parallel evolution in different systematic groups.

In the second place I may refer to the general hypothesis about the role of a modifier shift in evolution which I have developed (Brieger, 6). My observations started in 1929 when I observed in the cross Nicotiana Sanderae $\mathrm{x} N$. Longiflora that a gene, without effect in the latter species, acquired a semilethal effect in the Fl hybrid. An identical case was reported a year later by Hollingshead. In subsequent studies, I have been able to show experimentally the importance which a shift or rearrangement of the modifier complexes may have, and which may not only affact the dominance of certain characters, a fact allready very well konw by many authors, but may cause the appearence of completely new phaenotypes. Such a change in the modifier complex may be brought about by selection, artificial or natural, following a gen mutation which opens new phaenotipic possibilities or simply after a change in the direction of selection in material sufficiently heterozygous.

In the present paper $I$ have shown that there exists in cultivated maize an enormous amount of "inherent possibilities" which may become reality after changing the composition of the modifier complexes. Thus a "parallel evolution" may become started, or even a "reversion of evolution". It may be sufficient to cite the appearance of plants with two rows of three spikelets each, such as in Hordeum, or of many flowered spikelets as in the Paniceae.

Thus the facts reported here offer more support for the hypothesis on the importance of the modifier shift in evolution which seems to me a very efficient corollary to the mutation theory and helps to overcome at least one serious difficulty of the latter. Itis extremely difficult to believe that the accumulation and selection of disorderly chance mutations may cause an orderly evolution, Besides, the mutation theory is incompatible with such concepts as that of "inherent trends". But since the latter undoubtedly exist and since evolution is not disorderly, as shown by a very large number of comparative studies of larger taxonomical groups, an explanation for this 
orderliness must be found. I believ that the hypothesis of the modifier shift offers the necessary explanation, which is well in accordance whith experimental evidence, and with our concepts of physiological geneties.

\section{LITERATURA CITADA}

1. Arber, A. The Gramineae - A study of cereal, Bamboo, and Grass. Cambridge. Univ. Press. 480 pag. 1934.

2. Ascherson, P. Bemerkungen uber astigen Maiskolben Bot. Ver. Prov. Brandenburg. 21 ; 133-138. 1880.

3. Blaringhem, L. Production par traumatisme d'une forme nouvelle de mais à caryopsis multiples, Zea Mayz Var. Polysperma. Compt. Rend. Acad. Sci. (Paris) 170: 677-679, 1920.

4. Brieger, F.G. Origem do milho. "Semana da Genética". Rev. Agr. 18 : 409-418. 1943.

5. Brieger, F.G. Considerações sôbre o meeanismo da evolução. Anais da Escola Superior de Agricultura "Luiz de Queiroz", Piracicaba, 1: 177-211. 1944.

6. Brieger, F.G. Estudos Experimentais sôbre a origem do milho. Anais da Escola Superior de Agrieultura "Luiz de Queiroz", Piracieaba. 1 : 225-278. 1944.

7. Brieger, F.G. Estudos genéticos sôbre o milho tunicata. Anais da Escola Buperior de Agricultura "Luiz de Queiroz", Piracicaba: 2: 209-238. 1945.

8. Collins, J.N. Origin of maize. Jour. Wash. Acad. Sci. 2: 520-530. 1912.

9. Collins, J.N. Structure of the maize ear as indicated in Zea-Euchlaena hybrids. Jour. Agr. Res. 17: 127-135. 1919.

10. Cutler, H.C. Espiguetas de dois grãos no milho. Anais da Escola Superior de Agricultura "Luiz de Queiroz". Piracical)a. 2: (40:"

11. Goebel, K. Organographie der Pflanzen. Frgänzungsband 2. Jena. Gustav Fischer.

12. Huelsen, W. A. and M. C. Cillis. Inheritance of kernel arrangement in sweet corn. Illionois Agr. Exp. St. Bull. 320: 299-336. 1929.

13. Kemptn, J.H. Floral abnormalities in maize. U.S. Dept. Agr. Bur Plant Indus. Bull. 278, 18 pp. 1943.

14. Langham, D.C. The inheritance of intergeneric differences in Zea-Euchlaena hybrids. Genetics 25: 88-108 (Abstraet in Genotics, 1939, 24: 78). 1940.

15. Mangelsdorf, P.C. and G.R. Reeves. The origin of Indian corn the its relations. Texas. Agr. Exp. Sta. Bull. 574: 1939.

16. Nilson. H.N. Salix Laurina. Die Lösung einer mehr als 100 jährigen phylogenetischen Streitfrage, Fys. Selsk. Handl N.F. 39: 1-89. 1928.

17. Randolph, L.F. Developmental morphology of the caryopsis in maize Jour. Âgr. Res. 53: 881-916. 1936.

18. Stratton, M.E. The morphology of the double kernel in Zea Mays var. polysperma. N.Y. (Cornell) Agr. Exp. Sta. Mem. 69: 17 pp. 1923.

19. Tavear, A. Beitrag zur Vererbung der Kormreihenzahl an Maiskolben. Zeitsehr. $f$. Züehtung, 20: 364-376. 1935.

20. Weatherwax, P. The evolution of maize. Bull. Torrey Bot. Club. 45: 309-342. 1918.

21. Weatherwax, P. The phylogeny of Zea-Mays. Amer. Midland Nat. 16: 1-71. 1935.

\section{EXPLICACGĀO DAS FIGURAS}

Fig. 1 - a) Diagrama da flor das Liliaceae (E: eixo principal; Et: eixo lateral; B1, B2, B3; bráctcas estéreis.

b) Diagrama de uma espigneta típica (E: eixo principal; et: eixo da espigueta; Ge e Gi : glumas estéreis; L: lema; P: pálea; 1: lodículos).

c) Diagramas das espiguetas e flor do bambu (letras como na figcra anterior).

d) Esquema de uma espigucta bifloral (letras como na figura anterior). 
Fig. 2 - a) Diagramals de espriguetas com duas a três flores (explieação das letras como na figur: $1, a$ ).

Fig. 3 - a) até d) Esquemas de espiguetas com duas o três flores.

e) Alvéolo com duas espiguetas biflorais sésseis.

f) Alvéolo com racemo com três espiguetas biflorais.

Fig. 4 - a) Alvéolos isolados de flechas do milho tunicata, com grãos maduros nas espiguetas.

Fig. 5 - a-j) alvéolos isolados e k-1) pares de alvéolos com número variável de espiguetas do milho tunicata.

a até $g$ da planta 109-593-44; h atés 1 da planta 104-593-44.

Fig. 6 - a) Ramos de flechas do milho tunieata com alvéolos com duas ou mais espiguetas e com espiguetas com duas ou três flores.

a: da planta 104-593-44; b-c da planta 109-593-44.

Fig. 7 - Espiga assimétrica de um descendente (7-486-44) do cruzamento milho $x$ teosinto com duas fileiras de alvéolos c três fileiras de grấos por alvéolo. a: desenho de $\mathrm{um}$ grão isolado com a tapa protetora e a gluma externa; b: grão isolado; $c$ : gluma externa isolada; $d-e$ : vietas das duas faces dio csjiga mostrando a assimetria; f: vistas do flanco A; $g$ : vista do flaneo $B$.

Fig. 8 - Espigas de descendentes do cruzamento de milho $x$ teosinto.

a-b) vistas de lados opostos da espiga assimétrica da planta 11-487-44.

c-1) vistas da espiga simétrica da face e de flanco da planta 10-488-44.

Fig. 9 - Espigas de milho pipoca pontudo paulista com duas fileiras de grãos por alvéolos na parte apical e 3 e 4 filoiras na parte basall. a-b) da planta 8-571-42; c-f) da planta 33-591-42.

Fig. 10 - Espigas de descendentes do eruzamento milho $x$ teosinto com duas fileiras de alréolos na pirte apical o três filciras (e-f) ou quatro fileiras (a-d) na parte basal.

a-b - da planta 16-407-44.

c-d - da planta 27-372-44.

e-f - da planta 13-488-44.

Fig. 11 - Esquemas da interpolação de uma fileira adicional de alvéolos (a-c-e) ou duas fileiras adicionais (a-b-d).

Fig. 12 - Esquema do arranjamento dos alvéolos a até d: duas fileiras de alvéolos com filotaxia em espiral $1 / 2$; a : tipo original hipotético com racemos em eada alvéolo; b: tipo dos ramos da flecha de milho e teosinto e da parte masculina da inflorescência de Tripsacum; e: tipo da espiga de Euchla'na e da parte feminina da inflorescência de Tripsacum, com uma só espigueta séssil; $d$ : tipo básico de milho com duas espiguetas sésseis; e: intercalação do duas fileiras adicionais e substituição da filotaxia em espiral por fileiras longitudinais, conforme o esquema da fig. 11 ; $f$ : o acréseimo de novas fileiras, segundo a teoria de Collins (1919).

Fig. 13 - Formação de pares de espiguetas sésseis femininas e espiguetas peduneulaCas masculinas, formando fileitas regulares. a: ramo da flecha de milho tunicista com grãos maduros; b: ramo da fleeha de milho "tassel seed" durante o florescinento; e-d: espiga de um descendente do híbrido milho $\mathrm{x}$ tcosinto, 8-375-44, rista de dois lados.

Fig. 14 - Antocládios de dois descendentes do cruzamento milho $x$ teosinto, com espigas terminais $(n+1)$ ramifieadas $(r)$ a: planta $17-374-44 ; b:$ planta 5-374-44.

Fig. 15 - Ramificação dos antocládios em dois descendentes do cruzamento milho $x$ teosinto.

Fig. 16 - Espigas do descendente do cruzamento milho $x$ teosinto, 18-408-44. $\mathrm{a}$ : espiga ramificada terminal do antocládio; $b$ : espiga näo ramifirada lateral do antocládio; e-e: ramos vistos do lado ventral; $f$ : eixo nríncipal; g-i: ramos vistos do lado dorsal, da espiga ramificada. 
a
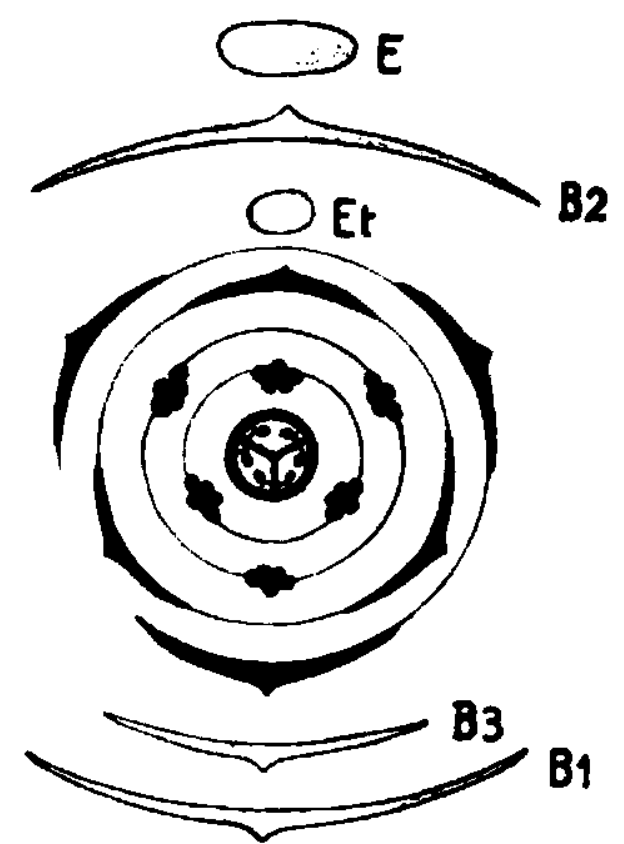

c
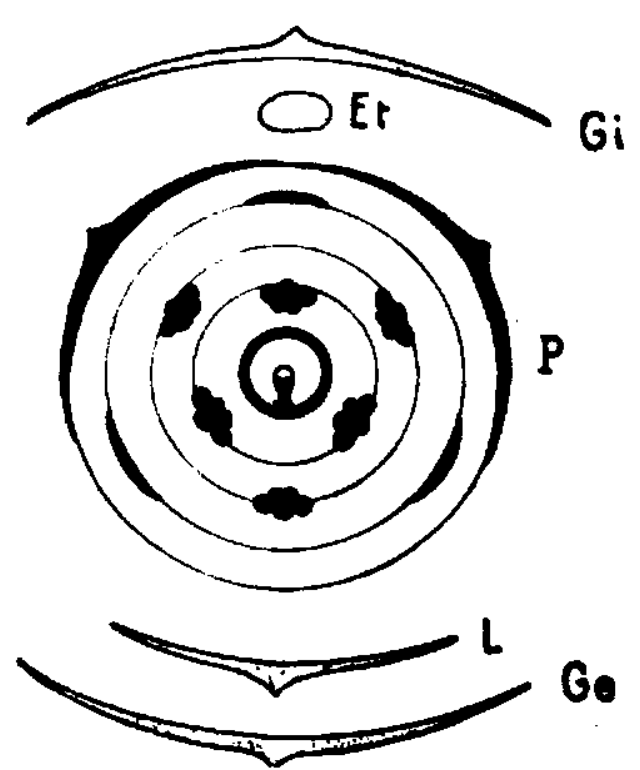

b

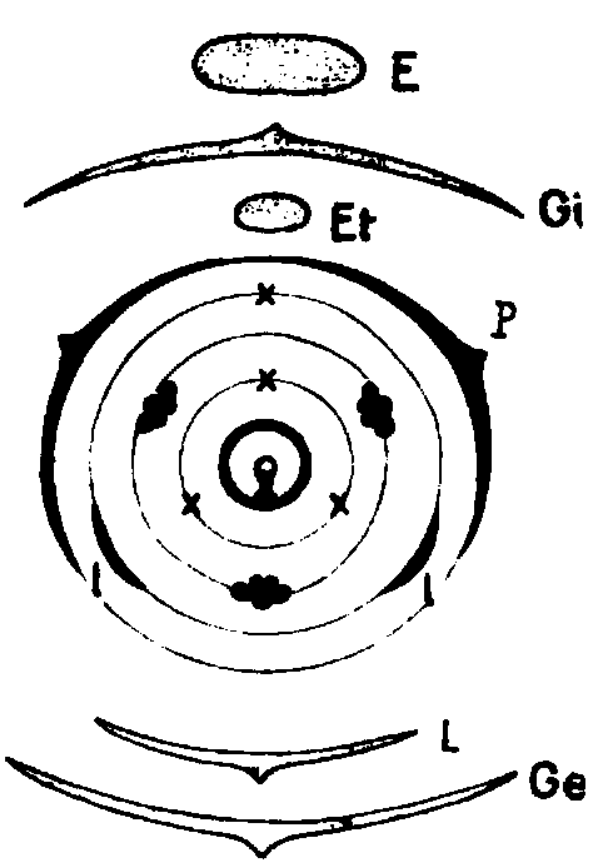

d
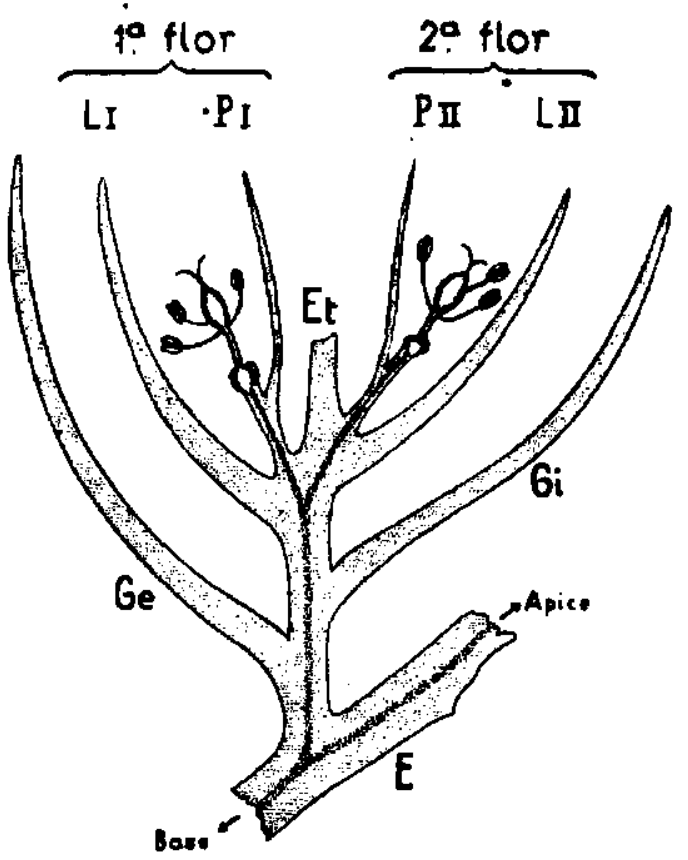

Fig. 1 


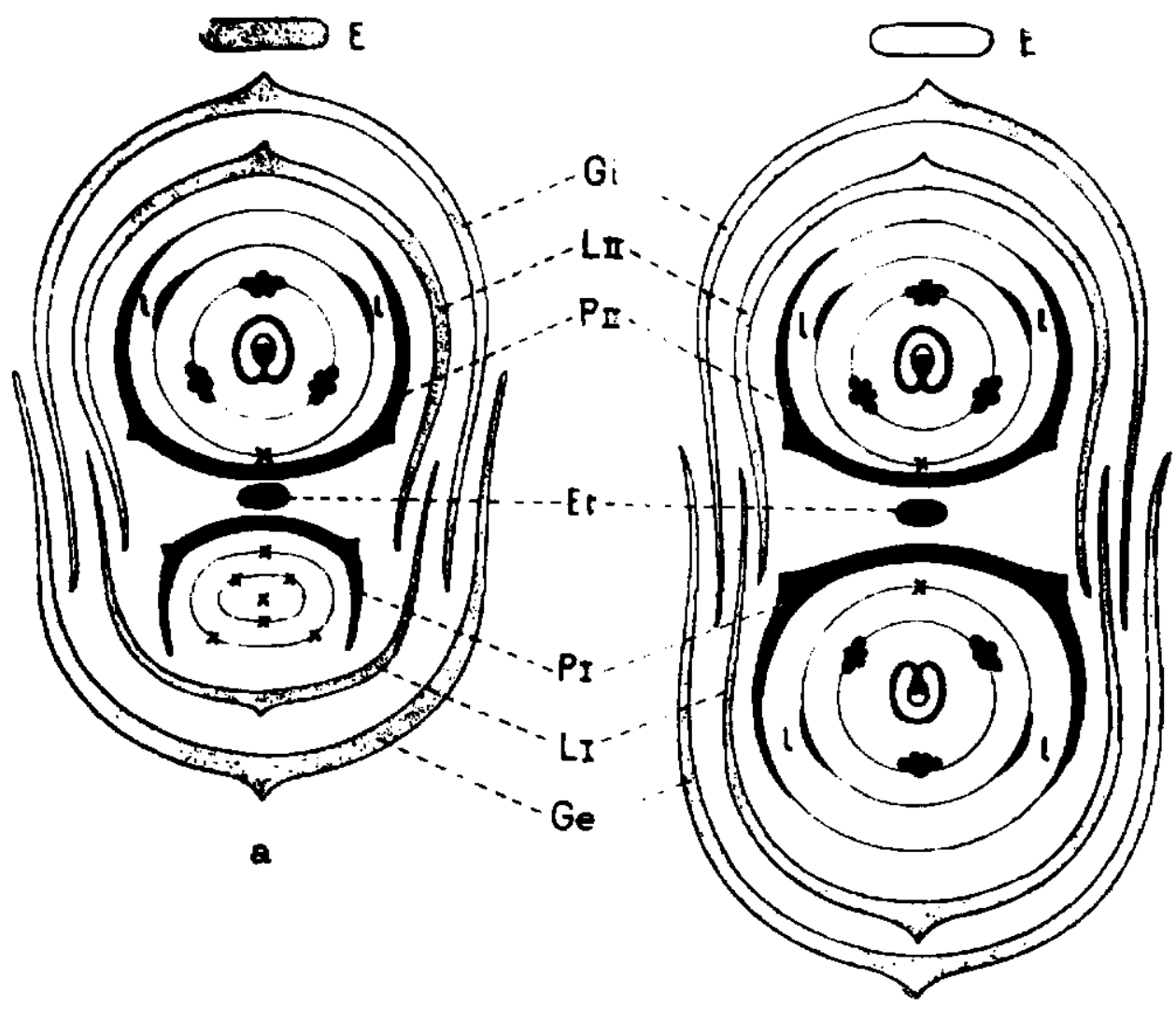

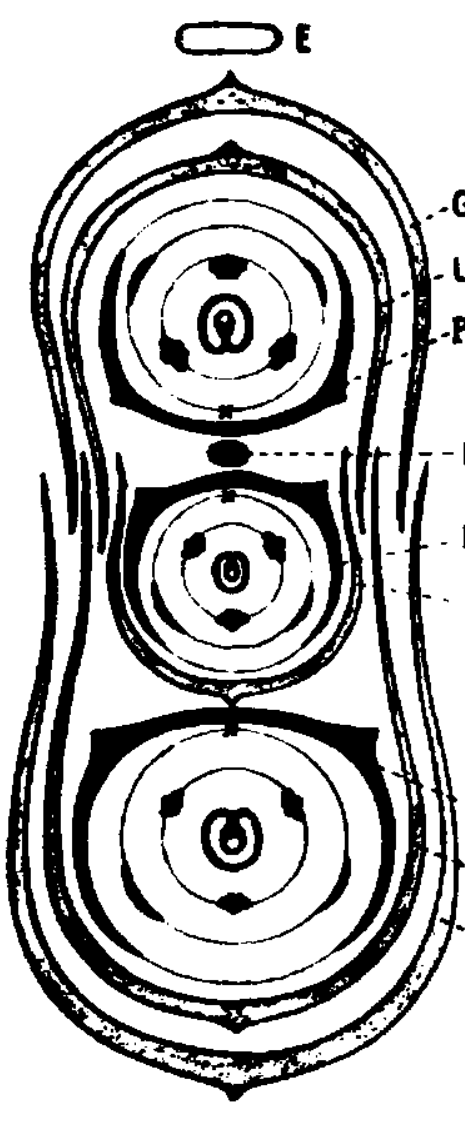

c
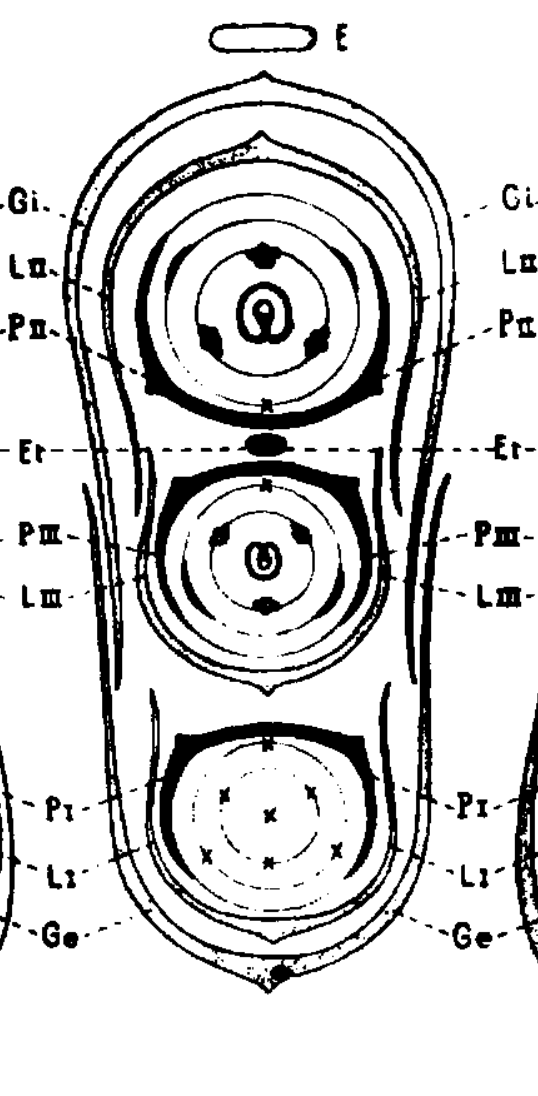

d

b 

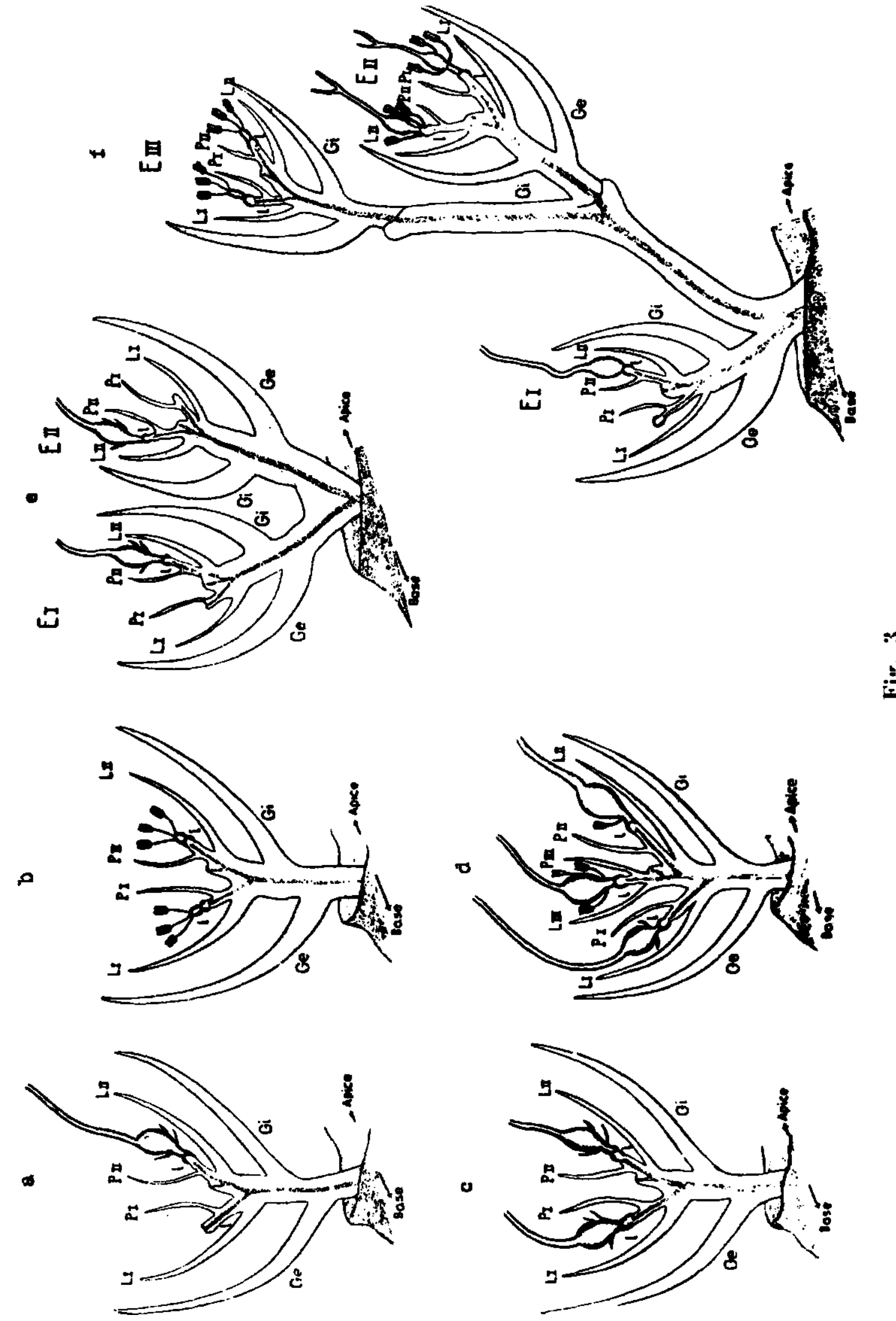


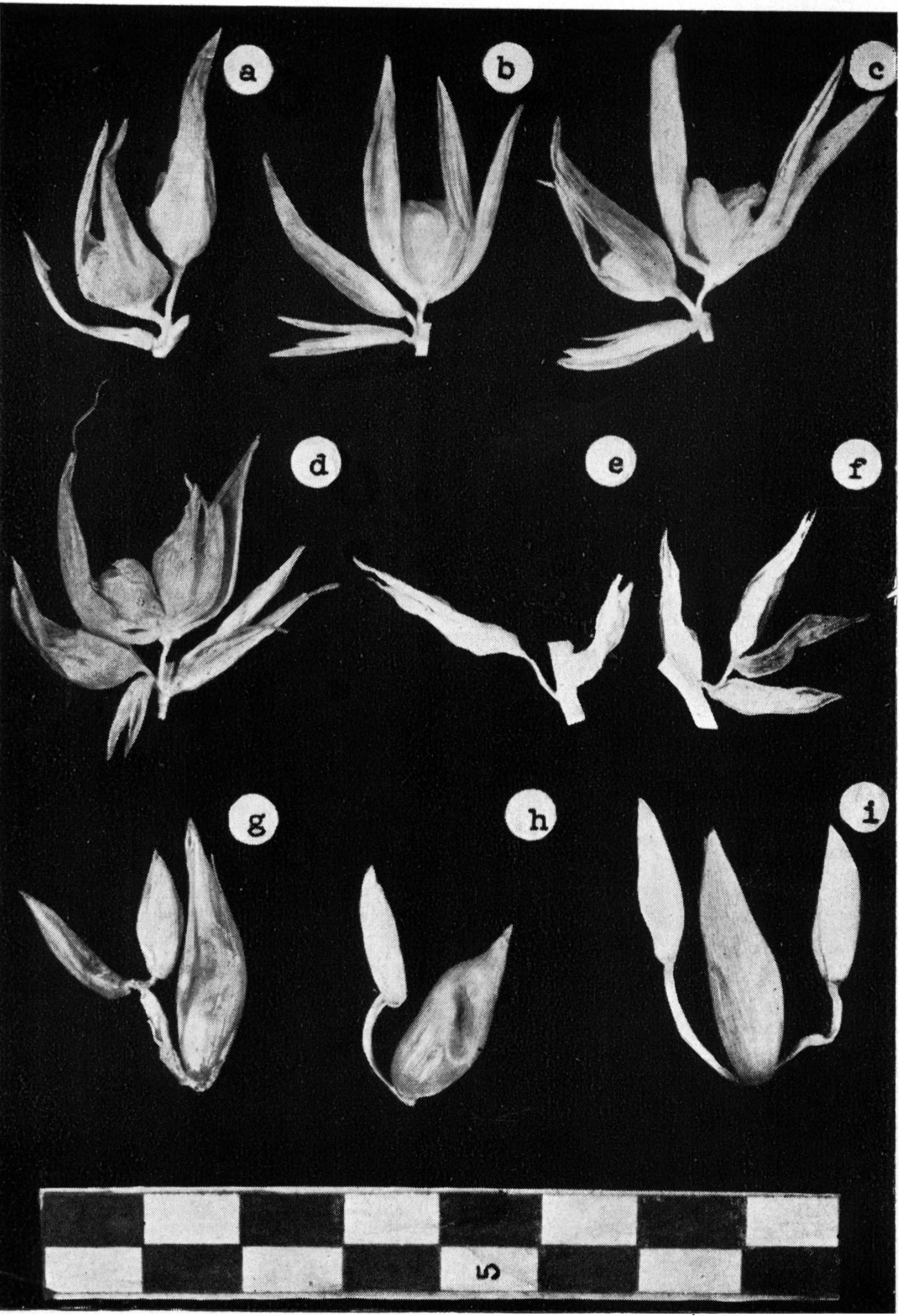

Fig. 4 


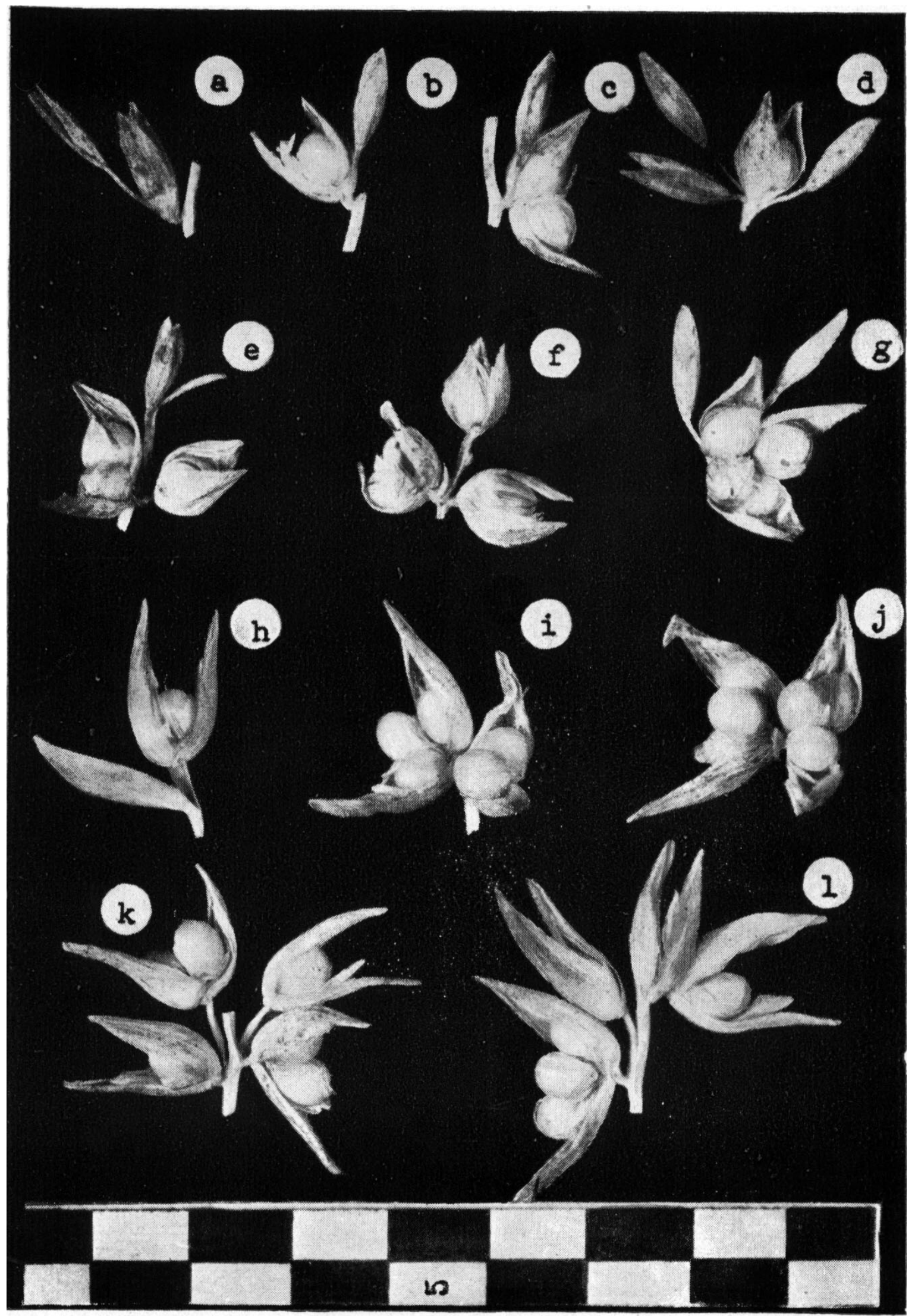

Fig. 5 


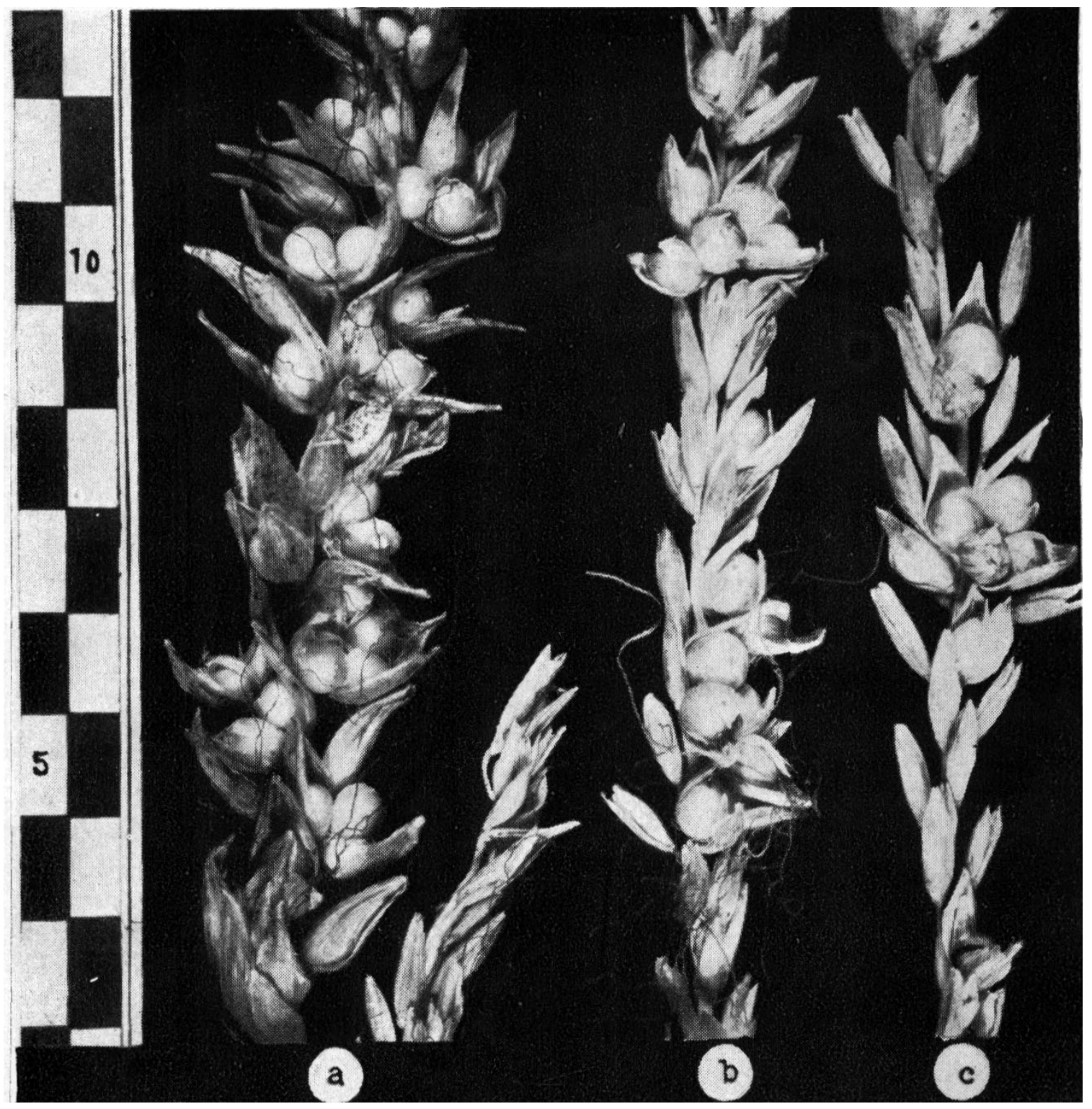

Fiz. 6 

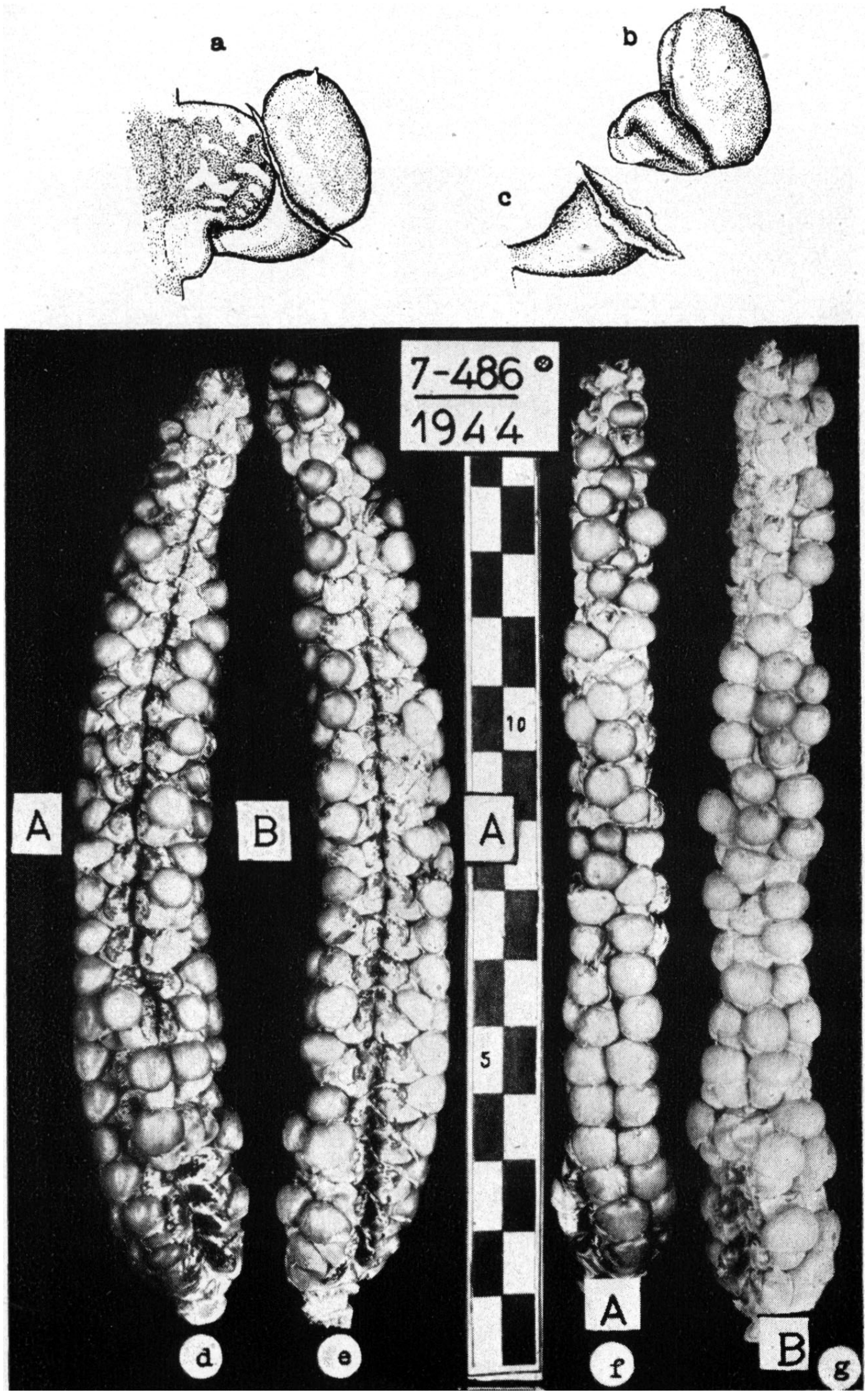

Fig. 7 


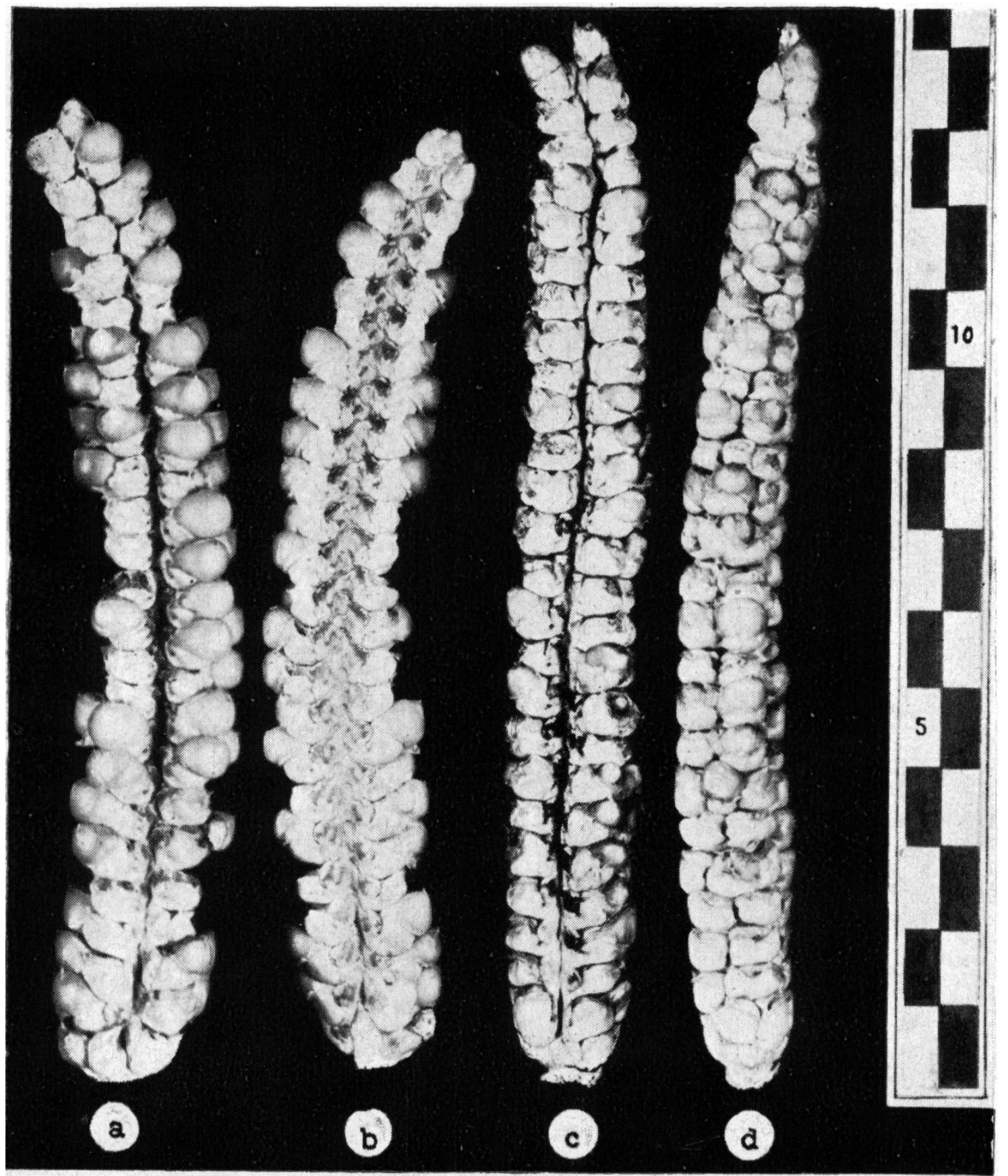

Fig. 8 


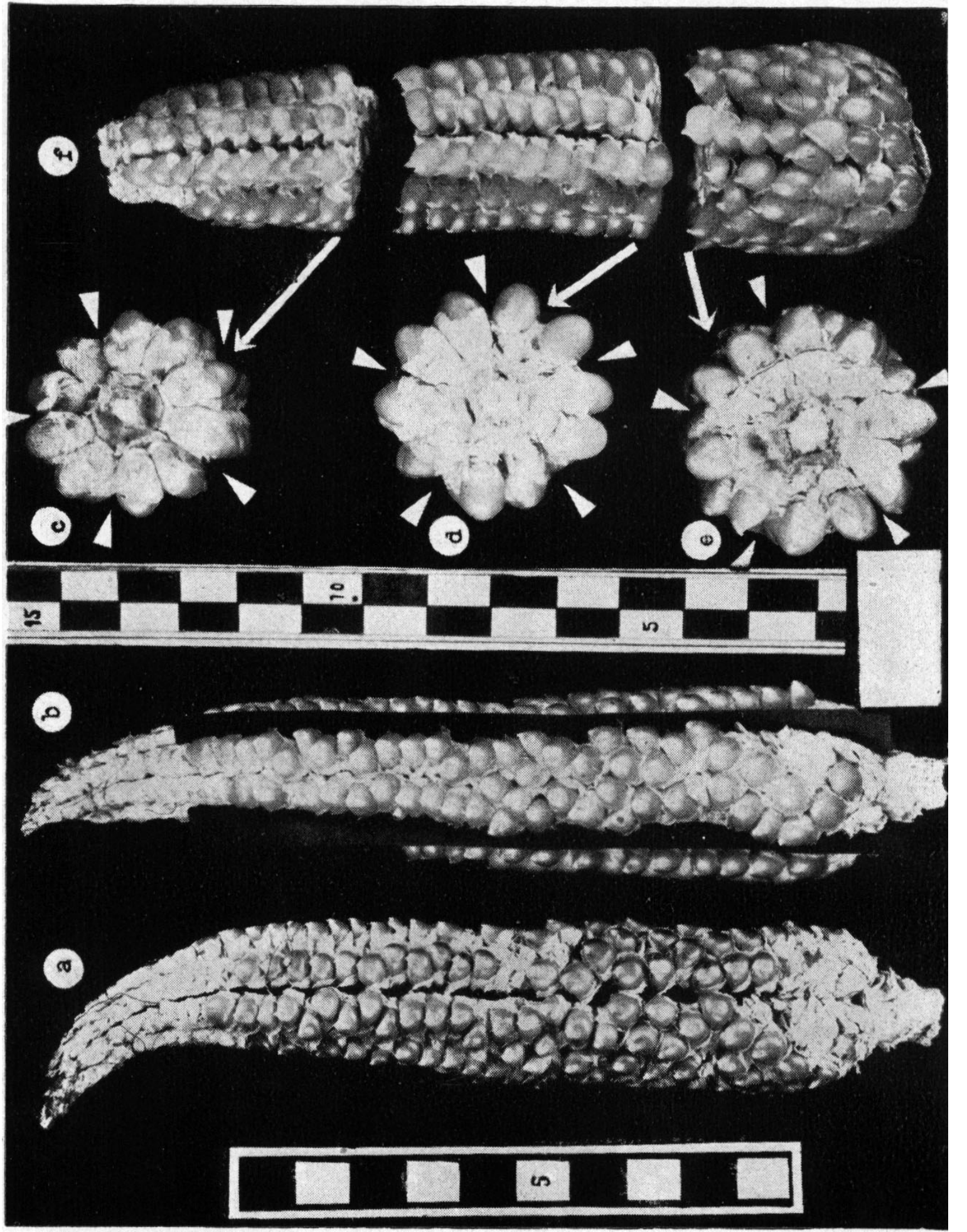

i 


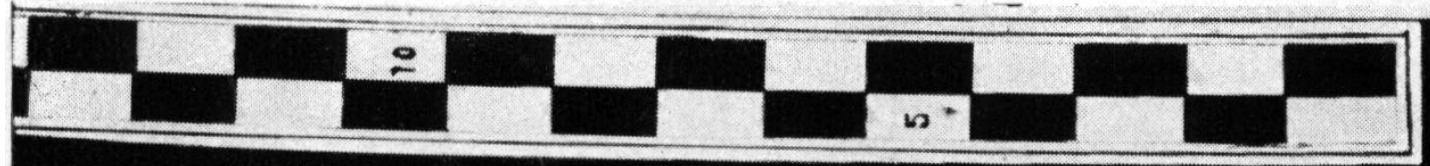

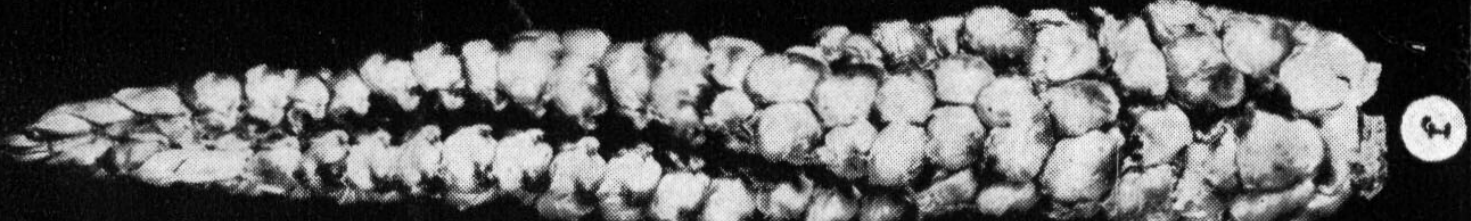

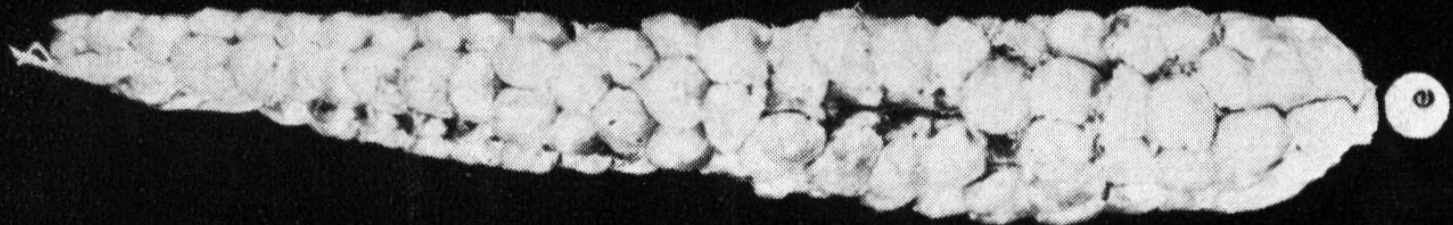

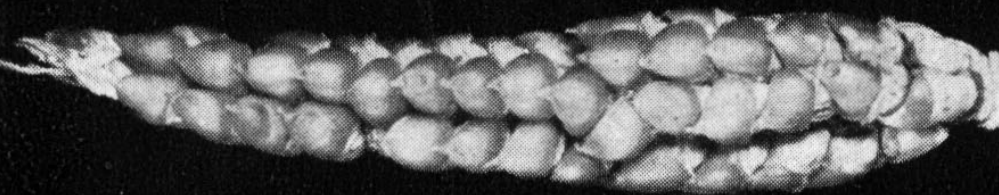

(b)

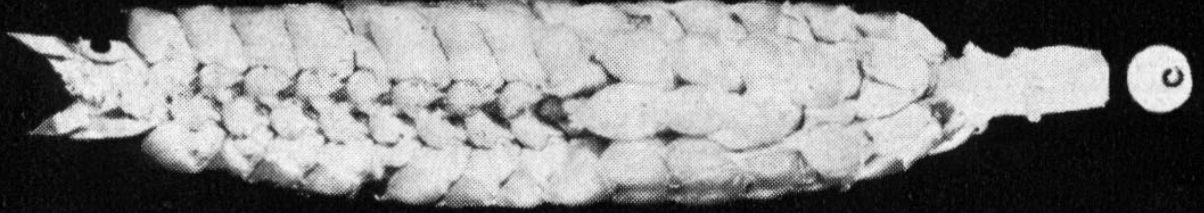

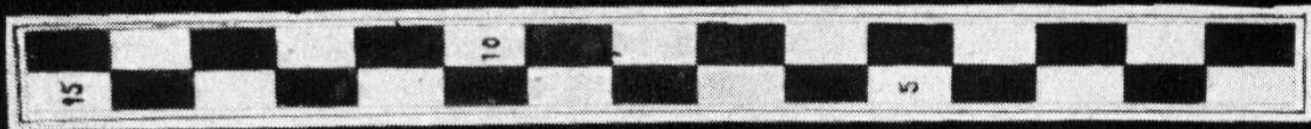

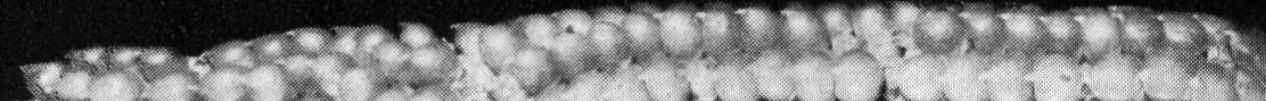

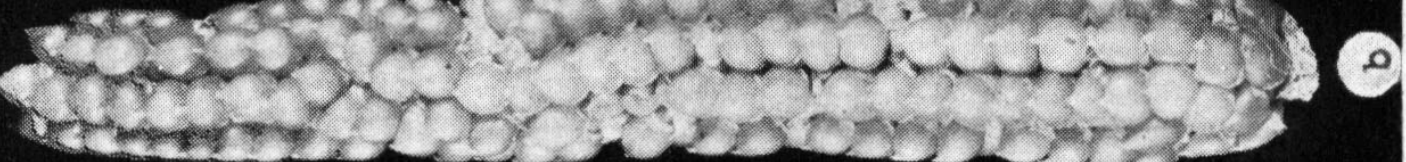

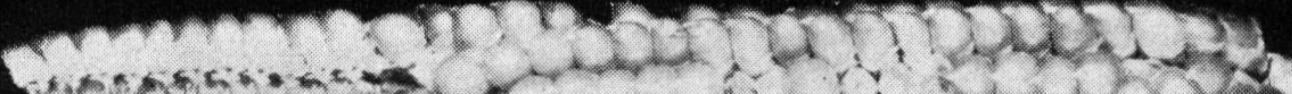

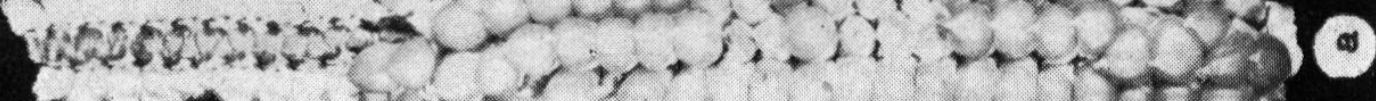

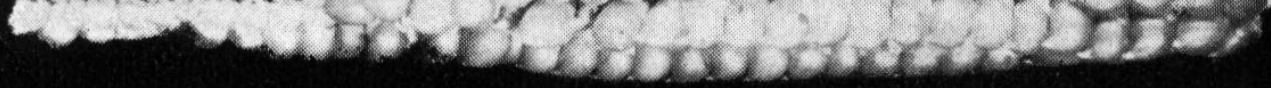




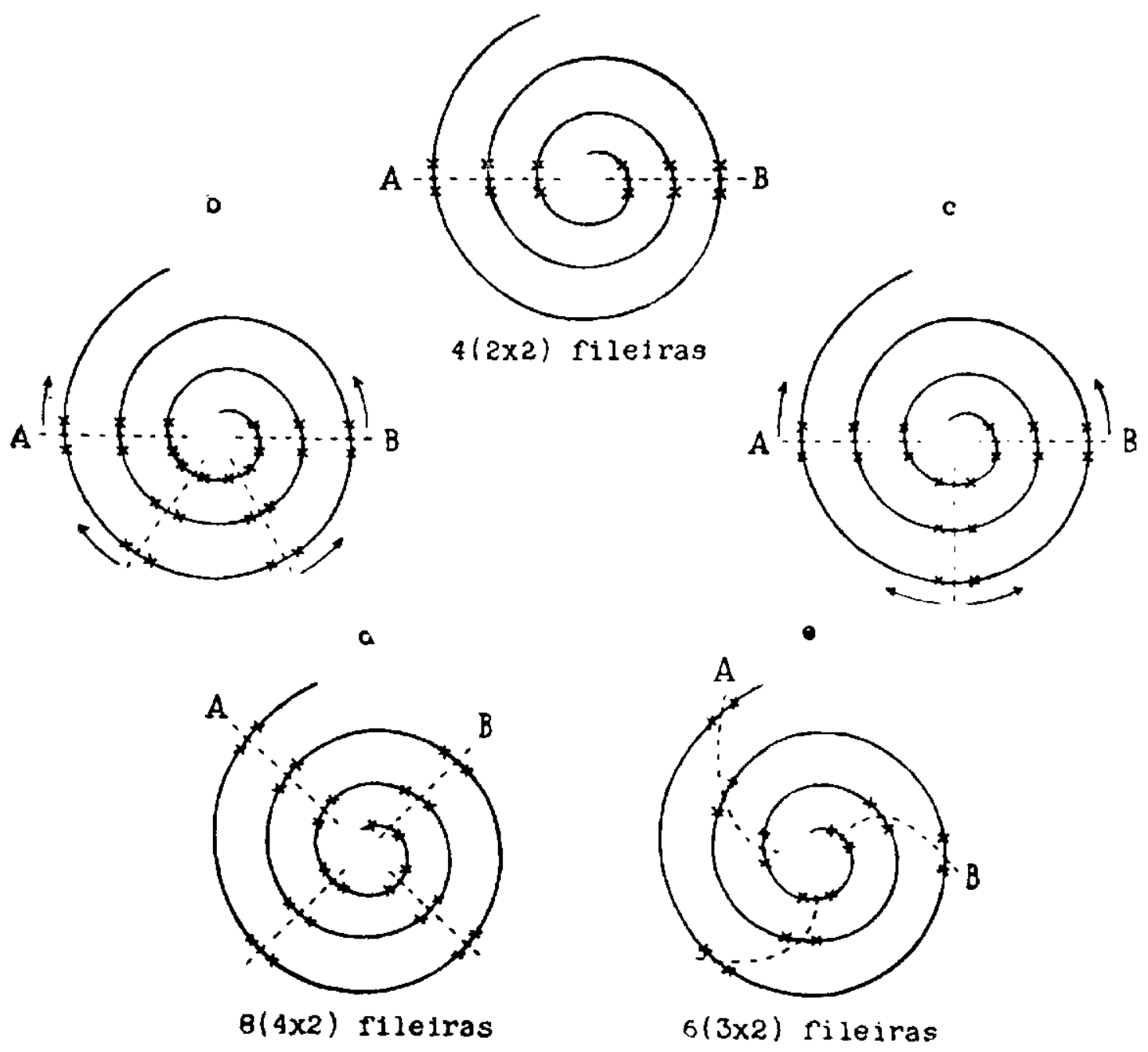

Fig. 11 

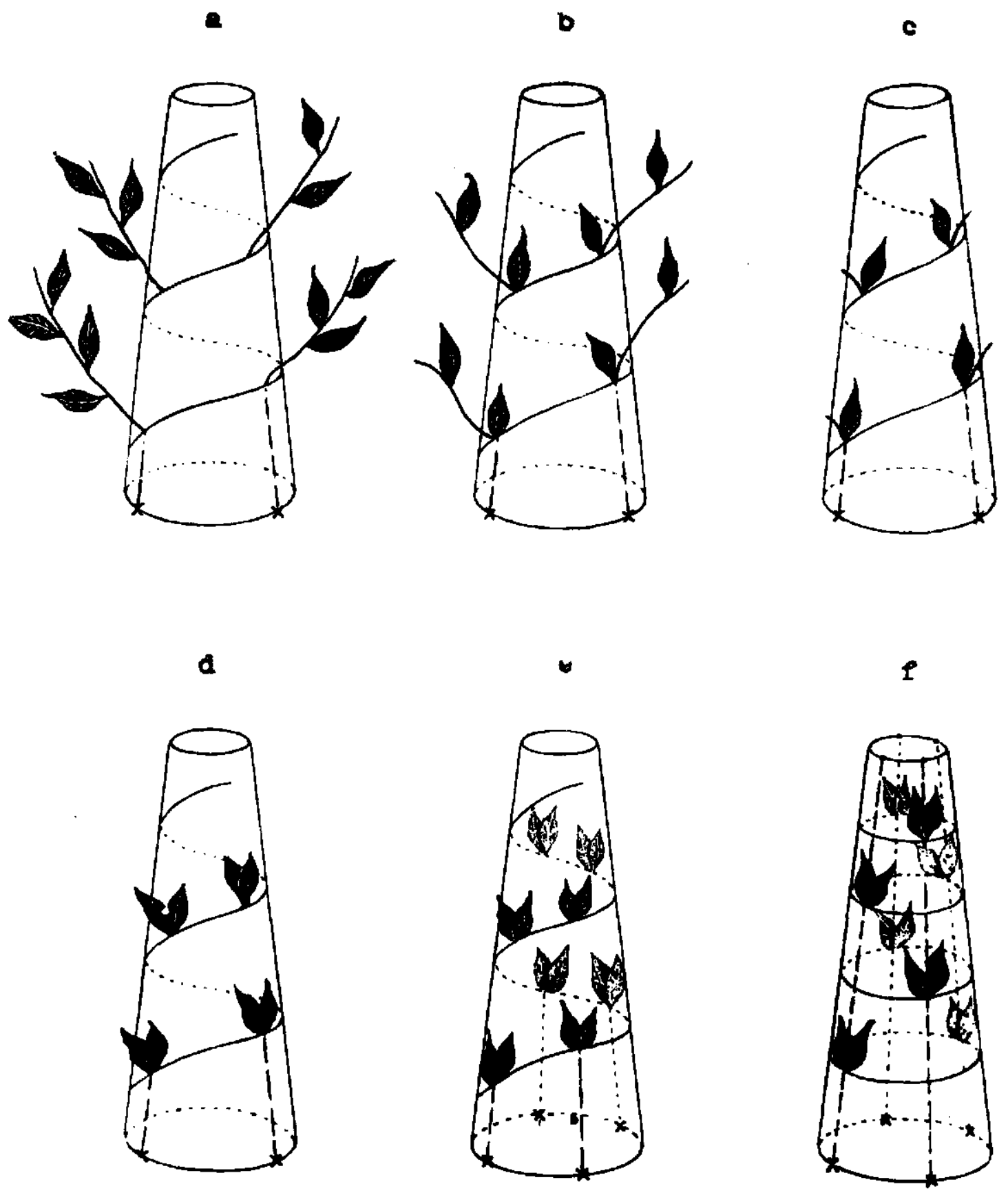

Fig. 12 


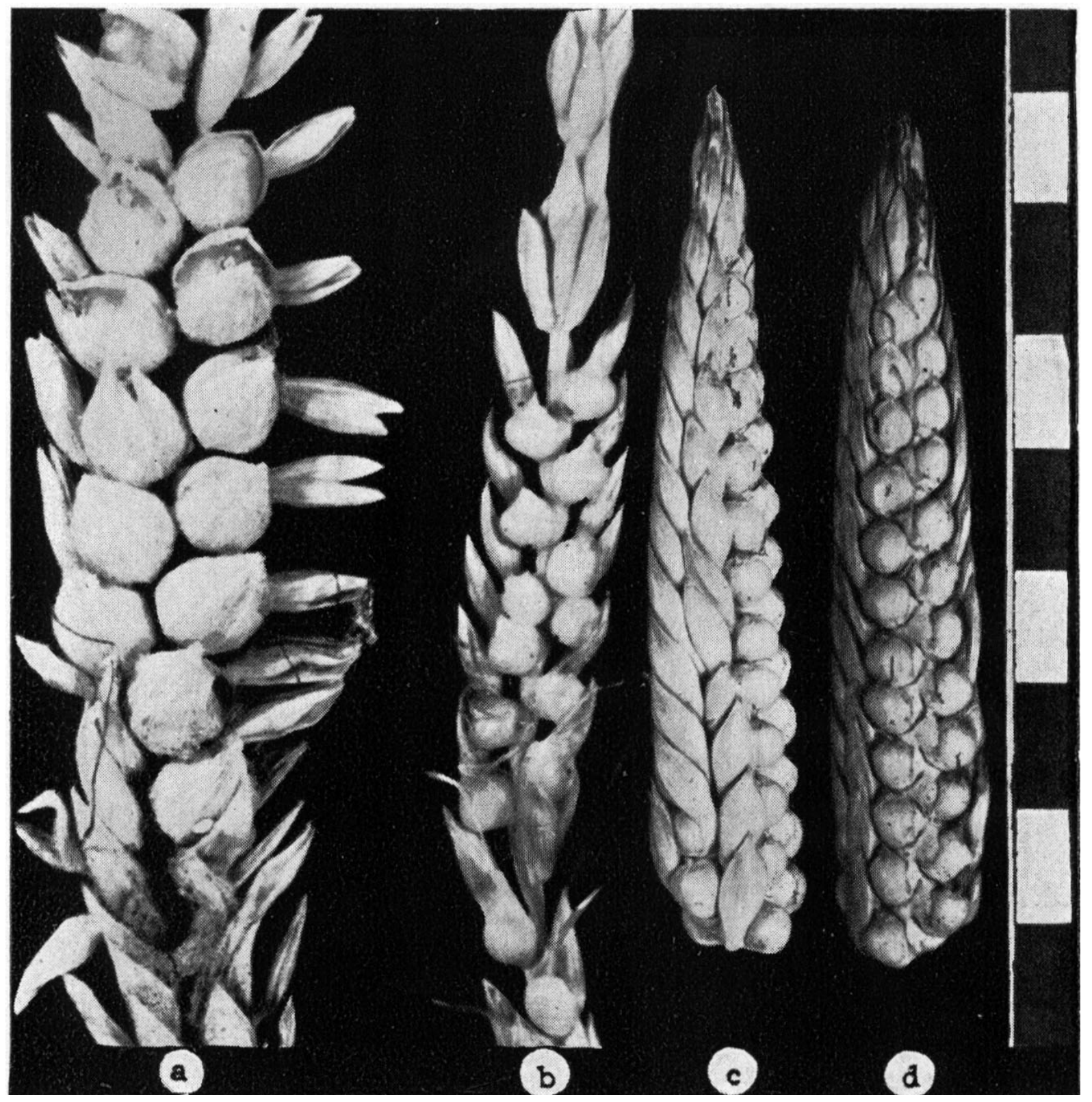

Fig. 13 


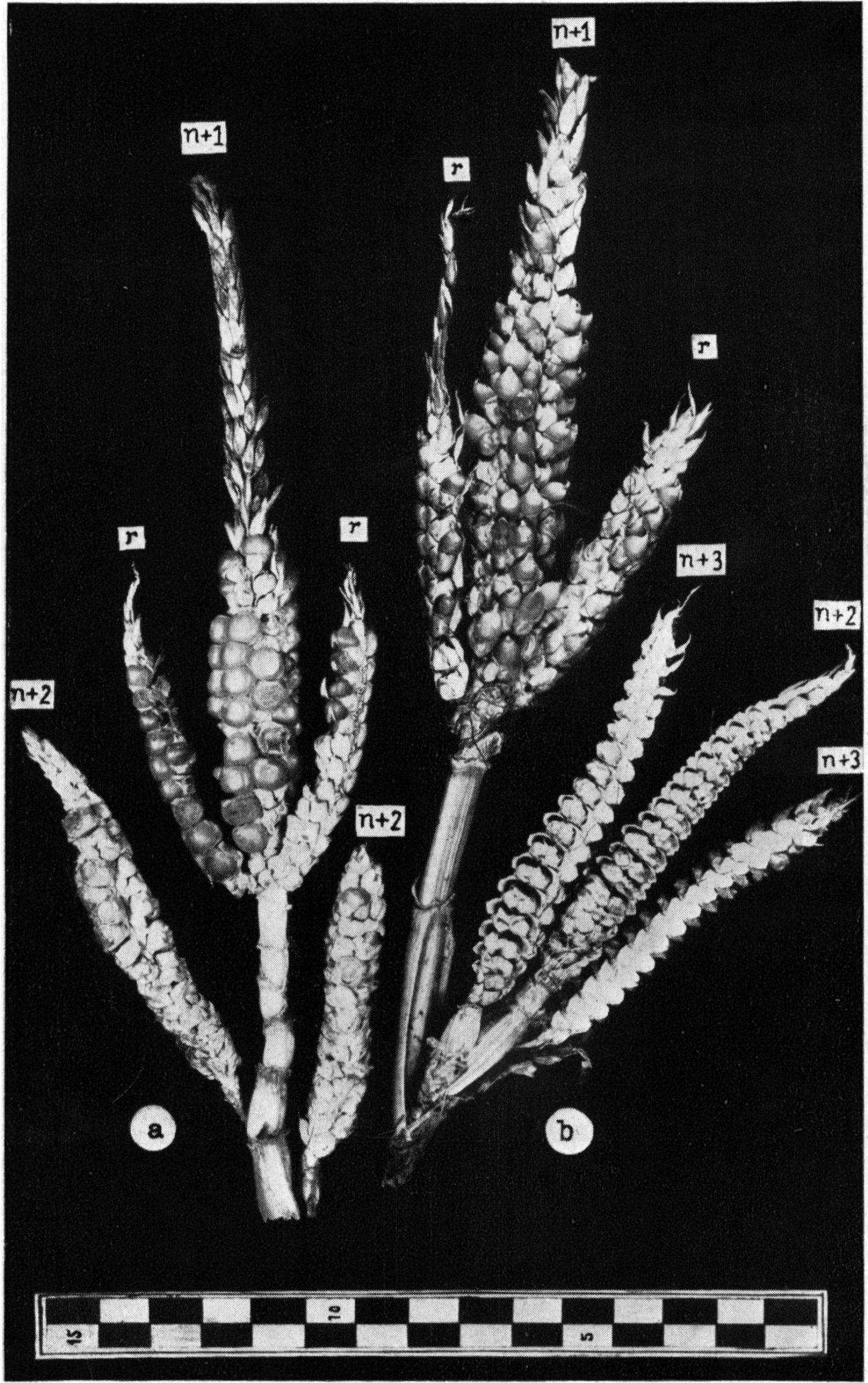

Fig. 14 


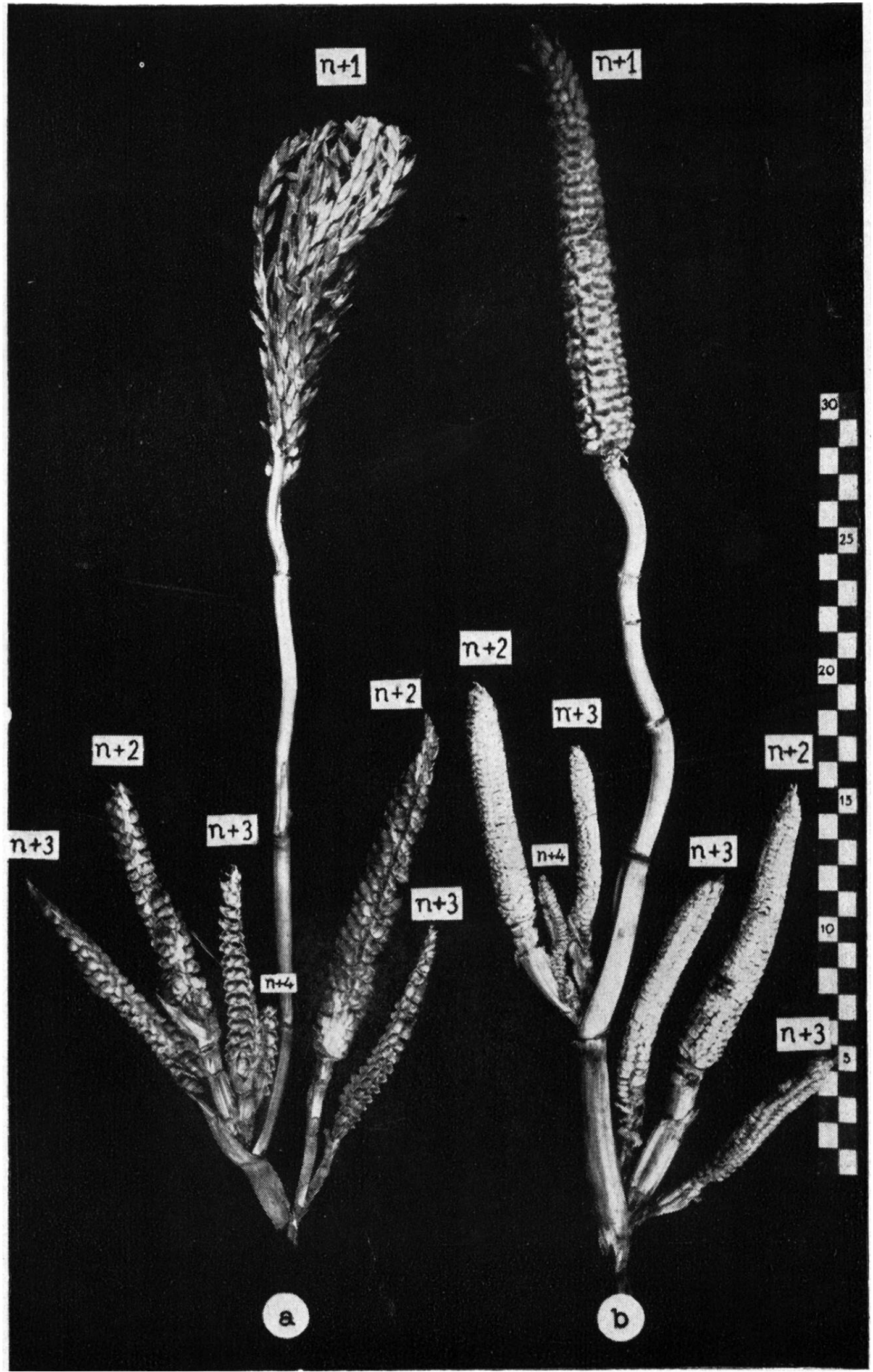

Fig. 15 


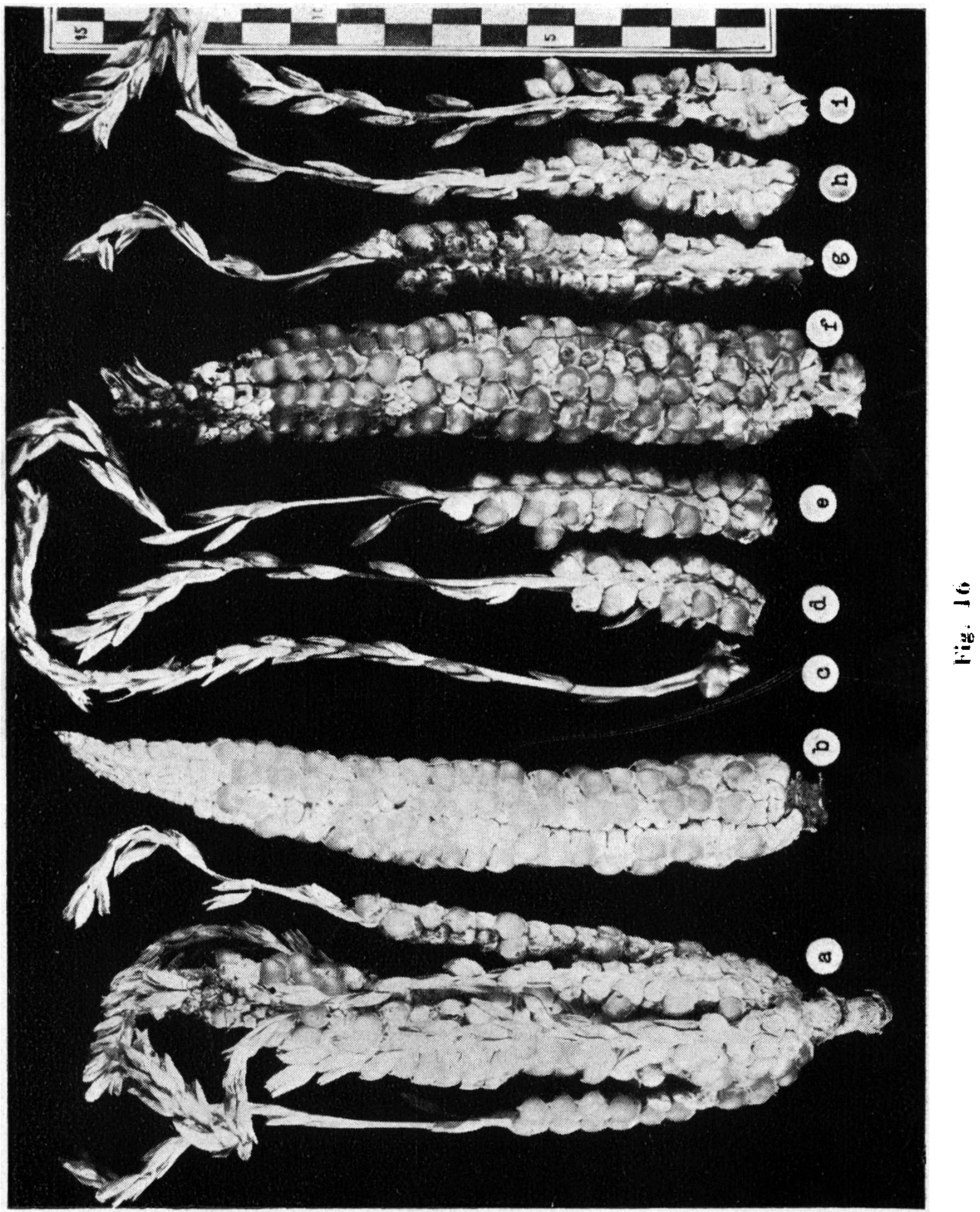

